\title{
Understanding the determinants of social network sites adoption at firm level: A mixed methodology approach
}

\author{
José Martins $^{\mathrm{a}, \mathrm{b}, *}$, Ramiro Gonçalves ${ }^{\mathrm{a}, \mathrm{b}}$, Tiago Oliveira ${ }^{\mathrm{d}}$, Manuel Cota ${ }^{\mathrm{c}}$, Frederico Branco ${ }^{\mathrm{a}, \mathrm{b}}$ \\ a University of Trás-os-Montes e Alto Douro, Vila Real, Portugal \\ ${ }^{\mathrm{b}}$ INES-TEC and UTAD, Vila Real, Portugal \\ ${ }^{\mathrm{c}}$ University of Vigo, Vigo, Spain \\ ${ }^{\mathrm{d}}$ Nova Information Management School, New University of Lisbon, Lisbon, Portugal
}

\section{A R T I C L E I N F O}

\section{Article history:}

Received 4 September 2015

Received in revised form 20 April 2016

Accepted 17 May 2016

Available online 20 May 2016

\section{Keywords:}

Social networks sites

Technology adoption

SNS adoption

Mixed methodology

\begin{abstract}
A B S T R A C T
The incredible numbers associated with social network sites makes technology a very attractive element in the eyes of organizations. Despite this, the existing scholarly literature does not demonstrate sufficient knowledge on how firms should adopt and use these technologies. With this lack in mind, a study was conducted aiming to understand what might be the determinants with the most influence on the SNS adoption process at firm level. the study was performed making use of a mixed methodology approach. In order to achieve an initial list of variables that might have a significant level of relative importance (RI) to the adoption of SNS, a Delphi study was designed and executed through the inclusion of 25 experts in the IT/IS area. From the Delphi results, a proposal for an adoption model that characterized the adoption of SNS at firm level was designed and validated through an empirical study. This empirical approach revealed that the proposed model explained $65 \%$ of variation in SNS adoption at firm level. The active involvement of top management, the alignment of the SNS plan with the firm's business plan, the existence of competitive pressures, and the use of SNS for gaining competitive advantages are the determinants with the most influence on technology adoption by firms.
\end{abstract}

(c) 2016 Elsevier B.V. All rights reserved.

\section{Introduction}

Since their initial creation, social network sites (SNS) have been receiving a serious amount of public attention, to the point of having millions of registered users and a billion hits per day (Agarwal et al., 2008; Kane et al., 2012; Kim et al., 2010). By perceiving the significance of SNS user registration numbers, firms started to direct their business efforts toward seizing the opportunities inherent to this massive adoption (Kaplan and Haenlein, 2010).

Conceptually SNS can be considered as a new class of information technologies (IT), given that they incorporate a range of new capabilities allowing them to stand out from the crowd and assume their own space in the Web technologies catalogue (Kane et al., 2012). Hence, and assuming Pai and Arnott (2013) arguments toward the characterization of SNS as Web based technologies that allow for a virtual representation (profile) of a user and, through

\footnotetext{
* Corresponding author at: University of Trás-os-Montes e Alto Douro, Vila Real, Portugal.

E-mail addresses: jmartins@utad.pt (J. Martins), ramiro@utad.pt (R. Gonçalves), toliveira@novaims.unl.pt (T. Oliveira), mpcota@uvigo.es (M. Cota), fbranco@utad.pt (F. Branco).
}

this profile, establish connections with other users to whom he then can communicate, SNS must be considered as fully individual technologies and the preconceived mindset that all IT are equally adopted and used must be adjusted. This is a research gap that needs to be addressed. Through honest and straightforward recognition of this reality, we believe that studying the factors affecting the adoption of SNS by firms is a relevant undertaking that will make a valuable contribution to both science and organizations (Jussila et al., 2014; Leonardi, 2014; Malik et al., 2016; Wu, 2013).

A literature review on the SNS adoption topic finds several works with interesting theoretical models for explaining the factors affecting this phenomenon (Cheng, 2010; Curtis et al., 2010; Mergel, 2013; Sarosa, 2012), the great majority of which focus on individual adoption. The focus of the present research, on the other hand, is to deepen our knowledge of the adoption of SNS at the firm level. In order to so, a mixed methodological (Venkatesh et al., 2013) approach was followed: (1) a Delphi study (Cebi, 2013; Okoli and Pawlowski, 2004) was executed in order to collect the consensual prediction of a group of experts on the factors that might impact the adoption of SNS at firm level, and (2) the development of an SNS adoption model - comprising the variables identified during the Delphi as the most important ones in the adoption 
process. that the model was then quantified by an empirical study involving 247 firms. By following this approach, we believe that the proposed adoption model is more robust and represents a valuable and innovative contribution to both science and organizations.

The paper is divided into seven sections, starting with an introduction to the context of the research. The second section is the conceptual arguments that support the research. In the third section the reader gains a detailed perspective on the research methodology chosen and its stages. In the fourth and fifth sections the empirical study and its results are described, and then discussed in Section 6. The seventh section presents some overall conclusions.

\section{Conceptual framework}

\subsection{Social network sites - SNS}

Social network sites are technological extensions based on all the properties and significances of "non-virtual" social networks, which, due to their Web essence have their features extrapolated. This essence allows for a substantial increase in the number of those receiving communication/input made within the SNS (Kaplan and Haenlein, 2010; Kim et al., 2010; Pai and Arnott, 2013). At the present there are several active social network sites and, even though the extent of functionalities may vary, ranging from simple communication tools to blogging and sharing of photos and videos, they maintain a fairly consistent goal of triggering the creation and maintenance of social networks whose members connect with each other according to their common interests, activities, nationalities, or political views. Still, despite their differences, the common denominator among the vast majority of social networking is that it allows users to create a public profile that displays a list of other users from that same SNS to whom the user is connected (Boyd and Ellison, 2007). Profile is an individual web page that displays all user inputted information, such as age, location, personal description, interests, and photos. In order to encourage the user adoption of these systems, they allow users to update their profiles by adding content generated by themselves or other multimedia content from multiple other websites and Web systems.

Even though the most known SNS perception is that they allow for the creation of connections (or relations) between individuals, the feature that allows for the conceptualization of these technologies to be unique is their ability to enable users to interact and connect with each other at the same time, allowing for a public display of the network of users to whom they are connected and with whom they interact. Therefore, a set of connections between users will be established not only with users to whom there is already a real-life connection, but also with others to whom they have no real-life affinity (Haythornthwaite, 2005). Nevertheless, on larger social networks sites users are not always trying to connect with others, but instead are indulging in a communication process with multiple users at the same time (Boyd and Ellison, 2007; Mislove et al., 2007).

During the last decade not only has the number of SNS increased, but also their complexity and number of registered users, which currently is in the hundreds of millions. This massive adoption has been encouraging several types of actions from entities belonging to almost every sector of society and transforming SNS into a hot topic and a venture for new business opportunities (Fang et al., 2013; Kane et al., 2012; Xu et al., 2012). By analysing today's business environment, one can easily perceive that it is becoming increasingly complex and more technological. This is mainly because existing customers are using newer technologies and platforms to build social groups, thereby triggering the devel- opment of relationships with others and promoting the exchange of product/service related content and feedback. This affects business behaviour and forces firms to adopt these technologies to answer the current market needs and trends (Berthon et al., 2012; Joo et al., 2011; Nosek and McManus, 2008). Proof of this massive SNS adoption is presented by Everson et al. (2013), who state that around two thirds of people who regularly go online use SNS.

Despite the difficulties in defining and characterizing SNS and what they represent as innovative technologies (Kaplan and Haenlein, 2010; Teng, 2015), a considerable amount of research has been undertaken focusing on this adoption. When analysing these studies one notices that the majority address SNS adoption at the individual level, while neglecting its adoption at the firm level - and providing a research opportunity. Authors such as Durkin et al. (2013), Kietzmann et al. (2011), and Ko (2013) have been arguing that this resulting knowledge gap is the origin of so many firms' unsuccessful SNS business initiatives and that deeper research is needed in this field of study. In parallel, Meske and Stieglitz (2013) highlight that, despite the incorporation of SNS within their business activities and initiatives, organizations still have issues concerning the adoption process and the identification of business opportunities and return on investments. This issue is so critical mainly because as companies recognize the necessity for being active in SNS, they also confess their inability to understand how to do so, which performance indicators to measure, and how to measure them (Hanna et al., 2011). Their concern is also expressed in the McKinsey Global Institute report on the social economy (Chui et al., 2012), according to which almost two thirds of companies use SNS in some way, but only a very small portion of these take full advantage of the potential these technologies have to offer, mainly because the most impactful uses of SNS in the global economy today are yet to be considered. Hence the need to improve knowledge on how firms may properly adopt SNS.

Currently firms are using SNS with three main purposes: (1) internal purposes; (2) customer oriented purposes; and (3) partners, suppliers, and external-expert purposes. Concerning the use with internal purposes, firms are trying to increase the speed at which their collaborators access information, are analysing and implementing mechanisms to reduce their communication costs, and are also seeking to increase the ease of access to internal expertise. Regarding the customer orientated purposes, firms hope to improve their marketing initiatives' effectiveness and their customer satisfaction while simultaneously driving down marketing costs. In terms of purposes related with partners and suppliers, firms are also trying to increase the speed of access to external knowledge and experts and, in parallel, to improve their communication processes' efficiency (Bughin et al., 2011).

According to Muñoz and Strotmeyer (2010) and Divol et al. (2012), the use of SNS has allowed firms to not only create a buzz for their brand, but also target customers and learn from them. These consequences are arising from the adoption of SNS as tools to monitor social trends and insights, interact with customers from a customer service perspective and a crisis management standpoint, amplify the benefits associated with products or services, and trigger (planned) behaviours from customers toward new deals, products, or brand changes.

Even though scholars have been thriving on the SNS topic and inherently producing considerable amounts of knowledge on it, the use of this technology at firm level is still very much clouded by a considerable amount of misinformation that, with some recurrence now, leads to problematic SNS use that may negatively impact a firm's business (Patel, 2016). This is even critical when acknowledging the awareness that SNS success might be defined for the number of comments and shares a given SNS post receives or by the count of visitors to a firm's SNS page (Gesenhues, 2013). 
Nonetheless, there are plenty of out-of-the-box introductory strategies to use SNS that firms may use in order to plan and accurately create their own SNS business initiatives, most of them focused on a constant monitoring of customer reactions and engagement supported by a comprehensive analysis of the firm's target group demographics and a thorough understanding of what competitors are doing and how they are doing it (Carter, 2016; DeMers, 2016).

Despite the inability of some firms to understand SNS and how to use it, there are several good examples of some that are using these technologies with great success (Patel, 2015; Patterson, 2015). One of the well-known examples of good SNS use is the one provided by GoPro, the leader in POV action cameras. This organization has taken full advantage of the user-generated content power in order to engage their customers by making simple, but decisive, business decisions, thereby allowing its users to actively form and participate in a global online community that not only shares their experience with the firm's cameras but also participates in spreading the brand name and image. In parallel, GoPro is also using its social media hype to find possible faults and future improvements to their products and services.

Another example of proper use of social networks sites is the one provided by JetBlue Airways, an airline industry firm for whom customer service is one of the most important assets to the firm's success. By presenting a response rate of over $70 \%$ on Twitter and an average response time of $9 \mathrm{~min}$, JetBlue delivers a proximity service to their customers, thus avoiding problems that could negatively impact the business. Another firm that is currently very much present in SNS is Dove, whose main focus has been bringing their female customers closer to the brand by creating content seeking to empower women and allow them to realize their beauty potential. This strategy, which also includes customers as actors that transmit the brand message, has led to considerable customer engagement and improvement in business results.

\subsection{SNS adoption at firm level}

The research team reviewed the literature which exists that is related to SNS adoption at firm level, seeking answers to the question(s): "Is there any relevant work focused on the central topic of our research? If so, what is the research methodology that supports it and what results were achieved?". The systematic literature review was directed at scholarly and scientific publications indexed by the Thomson Reuters Science Citation Index and the Elsevier Scopus Index. The review (Table 1) also relied on (Oliveira and Martins, 2011) as a guide for the analysis and presentation of the research identified and considered.

Through an extensive analysis of the literature on the adoption of social network sites at firm level, a clear perception of the need for a study supported by a mixed methodology aimed at delivering an overall characterization of the determinants that might influence SNS adoption at firm level was needed. With this in mind, the research team undertook the study reported herein.

\section{Research methodology}

The most common conceptualization of scientific research methodology highlights two distinct approaches: the qualitative and the quantitative methodologies. Qualitative methodologies were designed in the scope of social sciences with the aim of allowing researchers to study social and cultural phenomena and, in parallel, to understand people, firms, and the socioeconomic contexts in which they live (Neuman, 2005). Quantitative techniques, represented in this research by an empirical study, have their origin in the natural sciences area and aim to study and understand natural phenomena with an always present empirical perspective supported by mathematical and statistical techniques that guarantee reliability and accuracy (Creswell, 2013). This said, it is our opinion that if executed correctly, an empirical study will achieve valid and reliable results.

The natural evolution of scientific research methodologies and approaches, as well as the objects of studies associated with the information systems and technological areas, have prompted several claims that combining both qualitative and quantitative methodologies would be much more interesting, and that doing so would allow researchers to achieve results that characterize, in an improved manner, the reality of the study (Kaplan and Duchon, 1988; Maxwell, 2015; Venkatesh et al., 2013). Analysis of the various key points associated with the accomplishment of the present research, in combination with the acknowledgments mentioned above, allow us to assume that using a mixed methodology (qualitative and quantitative) is more appropriate for reaching the goal that was initially conceptualized: define and characterize a model that explains the adoption of social network sites at the firm level. Drawing on this assumption, a decision was made to conduct a Delphi study (qualitative) influenced by an interpretative epistemology, in combination with a posterior quantitative approach composed of a survey and influenced by a positive epistemology.

\subsection{Stage 1 - Delphi study}

When the existing scientific and technical literature does not provide for a clear perspective on a specific problem or topic and the only form through which one can reach the required knowledge is by collecting experts' opinions, the Delphi method might be considered appropriate (Gallego and Bueno, 2014; RodríguezMañas et al., 2013). Even though the original presentation of Delphi dates back to the early 1960 s (Dalkey and Helmer, 1963), according to Heiko (2012) and Varho et al. (2016) it continues to be a viable qualitative research method to be used under the conditions mentioned. As argued by Graefe and Armstrong (2011), Delphi based studies can also lead to more feasible results than other in-person methods, which highlights the accuracy of the method. As Delphi was initially used, it was considered a method that allowed researchers to perform studies supported by opinions obtained from a panel of experts through the implementation of individual and anonymous questionnaires aimed at reaching a significant level of consensus between the responses collected (Landeta, 2006).

With the frequent use of the Delphi method over the years, its own definition has undergone some changes. It is currently considered a socio-technical technique the main goal of which is to reach a consensual opinion from various experts that participate in the study in an anonymous manner (Rowe and Wright, 2011). As with other research methods, Delphi also has been the subject of a number of criticisms, mainly focused on the general lack of guarantee that the same study performed with two (or more) different panels of experts will reach the same final outcome (Marques et al., 2011). Considering these issues to be important, Landeta (2006), Paré et al., (2013), and Gallego and Bueno (2014) sought to demonstrate that Delphi's "lack of trust evidence" is not a genuine issue and that the results achieved through the use of the method are indeed valid and reliable.

Considering the scope of the present research project and its objectives, a Delphi study was performed. The Delphi study sought to establish a consensual opinion from various experts in SNS related topics (ex: IT/IS, management, customer engagement, and Web based business initiatives), on what might be the variables with the greatest influence on the adoption of social network sites by organizations. According to Rowe and Wright (2011), the Delphi 
Table 1

Analysis of the methodologies reported in peer review journals regarding SNS adoption at the firm level.

\begin{tabular}{|c|c|c|c|c|c|}
\hline \multirow[t]{2}{*}{ Title } & \multirow[t]{2}{*}{ Description } & \multicolumn{3}{|c|}{ Methodology } & \multirow[t]{2}{*}{ References } \\
\hline & & Qualitative & Quantitative & Mixed & \\
\hline $\begin{array}{l}\text { Usage, barriers, and measurement of social media } \\
\text { marketing: An exploratory investigation of } \\
\text { small and medium B2B brands }\end{array}$ & $\begin{array}{l}\text { E-mail survey aimed at identifying whether the UK's B2B } \\
\text { firms are adopting SNS and what the main barriers are that } \\
\text { influence the adoption process and the achievement of SNS } \\
\text { effectiveness }\end{array}$ & & $X$ & & $\begin{array}{l}\text { Michaelidou } \\
\text { et al. (2011) }\end{array}$ \\
\hline $\begin{array}{l}\text { From social media to social customer relationship } \\
\text { management }\end{array}$ & $\begin{array}{l}\text { A survey was sent to } 1056 \text { consumers from several } \\
\text { countries in order to understand what made them interact } \\
\text { with firms and in parallel another survey was sent to firms } \\
\text { from the same countries aiming to identify the factors } \\
\text { influencing their adoption of SNS to interact with } \\
\text { customers. In order to complement the research results, } 17 \\
\text { interviews were made with members of firmś executive } \\
\text { boards }\end{array}$ & & & $\mathrm{X}$ & $\begin{array}{l}\text { Baird and } \\
\text { Parasnis } \\
(2011)\end{array}$ \\
\hline $\begin{array}{l}\text { Adoption of social networking sites: an } \\
\text { exploratory adaptive structuration perspective } \\
\text { for global organizations }\end{array}$ & $\begin{array}{l}\text { By conducting a survey with } 72 \text { large firms followed by } \\
\text { interviews to high-level managers from these same firms, } \\
\text { researchers sought to clarify why firms use SNS and } \\
\text { identify what social network sites were used and how they } \\
\text { were being used }\end{array}$ & & & $\mathrm{X}$ & $\begin{array}{l}\text { Sinclaire and } \\
\text { Vogus } \\
(2011)\end{array}$ \\
\hline $\begin{array}{l}\text { Antecedents of Early Adoption and Use of Social } \\
\text { Media Networks for Stakeholder } \\
\text { Communications Evidence from Franchising }\end{array}$ & $\begin{array}{l}\text { Empirical study of } 408 \text { firms to understand the } \\
\text { determinants of SNS early adoption and use; Content } \\
\text { analysis of } 87 \text { firms' social network sites in order to } \\
\text { perceive whether the firms' characteristics influenced the } \\
\text { content published in these networks }\end{array}$ & & $\mathrm{X}$ & & $\begin{array}{l}\text { Perrigot } \\
\text { et al. (2012) }\end{array}$ \\
\hline $\begin{array}{l}\text { Adoption of Social Media Networks by Indonesian } \\
\text { SME: A Case Study }\end{array}$ & $\begin{array}{l}\text { Authors used semi-structured interviews to a firm CEO and } \\
\text { several collaborators in order to understand not only how } \\
\text { they are using SNS but also what has driven them to use } \\
\text { them in the first place. After collecting data, a set of content } \\
\text { analysis tasks were performed in order to achieve more } \\
\text { linear acknowledgments }\end{array}$ & $\mathrm{X}$ & & & $\begin{array}{l}\text { Sarosa } \\
(2012)\end{array}$ \\
\hline $\begin{array}{l}\text { Social media technology usage and customer } \\
\text { relationship performance: A capabilities-based } \\
\text { examination of social CRM }\end{array}$ & $\begin{array}{l}\text { Survey presented to } 330 \text { US firms seeking to understand if } \\
\text { SNS were being adopted in order to achieve greater access } \\
\text { to customer information and consequently increase firms' } \\
\text { CRM capabilities and performance }\end{array}$ & & $\mathrm{X}$ & & $\begin{array}{l}\text { Trainor et al. } \\
\text { (2013) }\end{array}$ \\
\hline $\begin{array}{l}\text { A comparison of social media adoption and use in } \\
\text { different countries: the case of the United } \\
\text { States and Switzerland }\end{array}$ & $\begin{array}{l}\text { An empirical study was performed in order to understand } \\
\text { marketing firms' adoption of SNS and whether top } \\
\text { management influenced the adoption process and if firms } \\
\text { have an awareness of the perceived success of adopting } \\
\text { these technologies. Data collection was made through a } \\
\text { survey sent via e-mail, receiving } 175 \text { complete and valid } \\
\text { responses }\end{array}$ & & $\mathrm{X}$ & & $\begin{array}{l}\text { Milwood } \\
\text { et al. (2013) }\end{array}$ \\
\hline $\begin{array}{l}\text { Social media adoption at the American grass roots: } \\
\text { Web } 2.0 \text { or } 1.5 ?\end{array}$ & $\begin{array}{l}\text { Seeking some perception on the determinants of SNS } \\
\text { adoption and use, researchers addressed a survey to } 1326 \\
\text { local governments in which they requested respondents to } \\
\text { give a perspective on the adoption of SNS in comparison to } \\
\text { the adoption of other e-government systems and } \\
\text { technologies }\end{array}$ & & $\mathrm{X}$ & & $\begin{array}{l}\text { Reddick and } \\
\text { Norris } \\
(2013)\end{array}$ \\
\hline $\begin{array}{l}\text { Social media adoption and resulting tactics in the } \\
\text { US federal government }\end{array}$ & $\begin{array}{l}\text { Qualitative interviews with } 15 \text { federal departments of the } \\
\text { US Government social media directors in order to } \\
\text { understand the factors influencing the adoption of SNS by } \\
\text { their departments }\end{array}$ & $\mathrm{X}$ & & & $\begin{array}{l}\text { Mergel } \\
(2013)\end{array}$ \\
\hline $\begin{array}{l}\text { The use of different information and } \\
\text { communication technologies to support } \\
\text { knowledge sharing in organizations: From e- } \\
\text { mail to micro-blogging }\end{array}$ & $\begin{array}{l}\text { A case study approach, supported by } 21 \text { interviews with } \\
\text { employees from a multinational firm, was used to study if } \\
\text { social media can address the knowledge sharing challenges } \\
\text { inherent to big firms. Results showed that SNS still do not } \\
\text { have the necessary set of features to support and trigger } \\
\text { knowledge sharing }\end{array}$ & $\mathrm{X}$ & & & $\begin{array}{l}\text { Yuan et al. } \\
\text { (2013) }\end{array}$ \\
\hline $\begin{array}{l}\text { The value of social media: are universities } \\
\text { successfully engaging their audience? }\end{array}$ & $\begin{array}{l}\text { With a focus on understanding the manner in which } \\
\text { American universities are using SNS, the authors used a } \\
\text { content analysis technique to observe } 30 \text { universities' } \\
\text { Facebook, Twitter, and YouTube accounts and observe the } \\
\text { methods and approaches that are being used by the } \\
\text { universities to engage with their students and overall } \\
\text { population }\end{array}$ & $\mathrm{X}$ & & & $\begin{array}{l}\text { Voss and } \\
\text { Kumar } \\
(2013)\end{array}$ \\
\hline $\begin{array}{l}\text { Modelling the adoption and use of social media by } \\
\text { non-profit organizations }\end{array}$ & $\begin{array}{l}\text { A research model aimed at characterizing SNS adoption by } \\
\text { non-profit organizations was created and empirically } \\
\text { validated in order to ensure if the variables identified in the } \\
\text { analysed literature had a significant influence on the } \\
\text { technologies' adoption }\end{array}$ & & $\mathrm{X}$ & & $\begin{array}{l}\text { Nah and } \\
\text { Saxton } \\
(2013)\end{array}$ \\
\hline
\end{tabular}

method aims to achieve a consensual opinion on a given topic from a panel of experts through individual and anonymous questionnaires. As several authors have argued, this method is favoured for studying issues concerning the information systems and technologies area of knowledge (Paré et al., 2013; Soares and Amaral, 2011; Sutton and Arnold, 2013). 


\subsubsection{Experts panel}

One of the key elements in performing a Delphi study is the definition of the panel of experts (specialists in their field who have a degree of knowledge, expertise, and experience on a given topic to the point of being considered by their peers as experts) from whom the opinions are going to be anonymously collected (Goluchowicz and Blind, 2011; Skulmoski et al., 2007; Worrell et al., 2013a). Following the guidelines of Skulmoski et al. (2007) and Worrell et al. (2013a), the experts chosen for the study belong to various social and economic contexts and have professional occupations that range from professors in public and private universities, to members of private firms, senior management and administration teams, and senior technicians of both central and local public administration. Drawing on Dalkey and Helmer (1963) and Marques et al. (2011), according a number of experts participating in the Delphi study, the panel should not be limited at the beginning, but adapted according to the context of the study (we did not present an initial limit to the number of experts to include in the study). These same authors also claim that an experts panel with 13 elements is capable of presenting a level of confidence of about 0.8 , and that this value does not significantly increase in studies with 30 or more experts.

In order to ensure the most reliable results, the Delphi experts panel must be methodically selected according to the following sequence of activities (Okoli and Pawlowski, 2004; Worrell et al., 2013b): (1) identification of the skills, topics of interest, and knowledge inherent to SNS; (2) search for experts that have profiles close to the previously identified topics; (3) contact the experts identified in order to confirm the profile information collected during the previous activity; and (4) rank the list of experts according to their professional, academic, or endemic expertise in social networks sites.

Once the Delphi expert panel members were selected, a set of 25 individuals representing Portuguese, Spanish, English, Mexican, and Thai private companies, Iberian public administration IT managers, and Iberian academics, was then assembled. Table 2 presents the key demographics of the experts' panel used for the Delphi study.

\subsubsection{Variables relevant to SNS adoption}

Even though the Delphi method's initial definition indicated that the variables to be evaluated in each round were only to be determined during the first round, Keil et al. (2002) argue that the research team performing the study should admit the possibility of adding new variables at a later time. A thorough and systematic analysis of earlier research on the adoption of Web related technologies and systems revealed a considerable number of influential variables. These were presented to the experts' panel for them to consider (Table 3 ).

\subsubsection{Data collection and results}

According to the Delphi method's conceptualization, it should base its results on the consensual opinion of a panel of experts. This consensus is determined by performing multiple rounds of questionnaires in which each expert transmits his/her opinion regarding a given topic. The questionnaire designed for this study was included all the variables identified as possible triggers of the SNS adoption process (Table 3), which the experts ranked according to their RI to the adoption process. According to Johnson and Lebreton (2004) and Tonidandel and LeBreton (2011) the concept of relative importance is has to do with the impact and influence that a given variable has on a certain action or event. Hence, by converging the perception of RI assumed during the research project and the overall objective of characterizing the SNS adoption process at firm level, and adhering to the arguments presented by Escobar-Rodriguez and Monge-Lozano (2012) and Venkatesh et al. (2012) regarding the need to consider the relative importance as an optimal metric to evaluate the impact that a given variable might have on the adoption process of technologies, the basis of the Delphi questionnaire will be the ranking of all variables identified, according to the experts' perceptions of their relative importance.

In order to ensure the fulfilment of all Delphi method requirements, the consensus criteria had to be defined, which according to Petry et al. (2007) is not an easy task, given that in order to be considered valid there must be at least $80 \%$ consensus between the experts' opinions.

For the present Delphi study, it was necessary to perform two separate rounds in order to ensure that the consensus between the variables' relative importance ranking was greater than $80 \%$. In each of the rounds the request for participating and the questionnaire were sent by e-mail. The e-mails mentioned a maximum response period of five weeks in order to ensure that the experts understood the importance of a timely answer. By collecting 18 answers in both rounds we were able to achieve a response rate of over $70 \%$ and, as argued by Dalkey and Helmer (1963), the study confidence level is greater than 0.8 .

At the end of each round an analysis of the results was performed in order to determine if the level of consensus between the experts' opinions was sufficient or if a new round was needed. The analysis of results was performed from two different perspectives: (1) using parametric statistical methods (average and standard deviation), and (2) using non-parametric statistical methods (Kendall's coefficient of concordance and Spearman's correlation coefficient) (Cafiso et al., 2013; Worrell et al., 2013a).

After a detailed observation of the results of the second round it was possible to see that both correlations were greater than 0.8 , thus establishing a consensus on the experts' opinions toward the variables with the most significant influence on the SNS adoption at firm level. By examining the results achieved after the first round of the Delphi study (Table 4), one sees that both Kendall's and Spearman's coefficients have correlation values less than 0.4 , which indicates a very low level of correlation between the initial position of the variables (alphabetic order) and the position resulting from the relative importance classification. The results indicate the need for a second round of questionnaires.

Rounds 1 and 2:

- Pearson's correlation coefficient is 0.944 and $p<0.001$;

- Kendall's correlation coefficient is 0.835 and $p<0.001$;

- Spearman's correlation coefficient is 0.944 and $p<0.001$;

Table 4 shows an overall comparison between the results achieved in both rounds of the Delphi study. Given a request made to the experts, the study not only ordered the entire set of variables according to their RI, but also reported individually on each

Table 2

Delphi panel individual demographics.

\begin{tabular}{|c|c|c|c|c|c|c|c|c|}
\hline \multicolumn{3}{|l|}{ Education Level } & \multicolumn{3}{|c|}{ Professional Group } & \multicolumn{3}{|c|}{$\begin{array}{l}\text { Years of Professional } \\
\text { Experience (years) }\end{array}$} \\
\hline Undergraduate Degree & Masters & $\mathrm{PhD}$ & Academics & Public Administration & Private Companies & $0-5$ & $5-10$ & $>10$ \\
\hline $28 \%$ & $32 \%$ & $40 \%$ & $40 \%$ & $12 \%$ & $48 \%$ & - & $48 \%$ & $52 \%$ \\
\hline
\end{tabular}


Table 3

Additional variables identified in the literature as influencers of Web technologies and systems adoption, presented to the experts' panel in the first round of the study.

\begin{tabular}{|c|c|c|}
\hline Variables & Description & Author(s) \\
\hline $\begin{array}{l}\text { Alignment of SNS Plan } \\
\text { with Business Plan }\end{array}$ & $\begin{array}{l}\text { A firm must adapt its SNS plan in order to support the business strategy, must create sturdy } \\
\text { linkages between SNS objectives and business objectives, and has to perform correct and } \\
\text { accurate assessments of the external environment }\end{array}$ & $\begin{array}{l}\text { Hendersen and Sifonis (1988), Kearns and } \\
\text { Lederer (2004), Pereira et al. (2014) }\end{array}$ \\
\hline $\begin{array}{l}\text { Business Dependence } \\
\text { on IT }\end{array}$ & $\begin{array}{l}\text { The business dependence on IT construct represents the extent to which a firm's business } \\
\text { activity depends on IT }\end{array}$ & Huang (2010), Kearns and Lederer (2004) \\
\hline Coercive Pressures & $\begin{array}{l}\text { Coercive pressures are those applied to a firm from other firms upon which it depends such as } \\
\text { resource-dominant firms, parent firms, and regulatory bodies }\end{array}$ & $\begin{array}{l}\text { Dimaggio and Powel (1983), Teo et al. } \\
\text { (2003) }\end{array}$ \\
\hline Normative Pressures & $\begin{array}{l}\text { Normative pressures can be represented through a firm's ability to learn and adopt a given } \\
\text { behaviour or action if a leader in its industry or environment has already adopted that same } \\
\text { behaviour or action }\end{array}$ & $\begin{array}{l}\text { Dimaggio and Powel (1983), Teo et al. } \\
\text { (2003) }\end{array}$ \\
\hline Mimetic Pressures & $\begin{array}{l}\text { Mimetic pressures can be represented in two ways: the prevalence of a given action or } \\
\text { behaviour from the firms' industry leader and the perceived success of those same actions and } \\
\text { behaviours from the firms' industry leader }\end{array}$ & $\begin{array}{l}\text { Dimaggio and Powel (1983), } \\
\text { Messerschmidt and Hinz (2013), Teo et al. } \\
\text { (2003) }\end{array}$ \\
\hline Compatibility & $\begin{array}{l}\text { The compatibility construct represents the extent to which an innovation is reliable and } \\
\text { compatible with the firm's procedures, familiarities, and values }\end{array}$ & Ifinedo (2011) \\
\hline Competitive Pressure & $\begin{array}{l}\text { Competitive pressure represents the degree of pressure felt by the firm from its competitors } \\
\text { within the industry that force the adoption of technologies and innovations as a trade-off for } \\
\text { maintaining (or increasing) its competitiveness }\end{array}$ & Ifinedo (2011) \\
\hline Complexity & $\begin{array}{l}\text { Complexity refers to the extent to which a given innovation or technology is perceived as } \\
\text { difficult to use and understand and/or will influence in a negative manner the adoption } \\
\text { behaviour }\end{array}$ & Ifinedo (2011) \\
\hline Globalization Level & $\begin{array}{l}\text { A firm's globalization level is represented by the extent to which its operation is spread across } \\
\text { several markets and with a variety of physical locations, thus making it imperative to become } \\
\text { more efficient and streamlined }\end{array}$ & Hsu et al. (2006), Xu et al. (2004) \\
\hline Government Pressure & $\begin{array}{l}\text { The regulatory institutions are able to create and promote laws and requirements that firms } \\
\text { must comply with in order to do business with the government, and are also able to create and } \\
\text { sponsor incentives for those firms that adopt a given technology or practice }\end{array}$ & Hsu et al. (2006) \\
\hline $\begin{array}{l}\text { IT Participation in } \\
\text { Business Planning }\end{array}$ & $\begin{array}{l}\text { CIOs should be included in the firm's administration decision making processes in order for } \\
\text { them to identify what the IT related adjustments are that must be implemented in order for } \\
\text { these technologies to be oriented in the same direction as the business plans }\end{array}$ & Kearns and Lederer (2004) \\
\hline Lack of Interoperability & $\begin{array}{l}\text { In order for a firm to take full advantage of SNS an integration of this technology with firm's } \\
\text { remaining systems and with the firm's partners systems must occur }\end{array}$ & Teo et al. (2006) \\
\hline Need for Privacy & $\begin{array}{l}\text { The SNS (as other ITs) inherent features tend to foster communication and data management, } \\
\text { thereby transforming the need for information and data privacy in an influencing factor for the } \\
\text { adoption of SNS at firm level }\end{array}$ & Messerschmidt and Hinz (2013) \\
\hline $\begin{array}{l}\text { Perceived Industry } \\
\text { Pressure }\end{array}$ & $\begin{array}{l}\text { Perceived industry pressure is used in this study to represent the pressures felt by a firms' } \\
\text { industry (i.e. business partners and competitors) }\end{array}$ & Hsu et al. (2006) \\
\hline Readiness & $\begin{array}{l}\text { Firm's readiness concept indicates whether a firm has the required levels of financial resources } \\
\text { and IT sophistication needed for using a given technology or innovation. For this research, the } \\
\text { Readiness construct has three sub-constructs: Financial Resources, IT Sophistication, and } \\
\text { Trading Partner Readiness }\end{array}$ & Chwelos et al. (2001) \\
\hline Regulatory Concerns & $\begin{array}{l}\text { When a firm has concerns about inadequate legal protection from those doing business online } \\
\text { or some legislation gaps, it may feel a need to avoid that behaviour }\end{array}$ & Hsu et al. (2006), Kuan and Chau (2001) \\
\hline Relative Advantage & $\begin{array}{l}\text { The degree to which an innovation is perceived as being better than the idea it supersedes is } \\
\text { called relative advantage. The existence of possible benefits and advantages will act as positive } \\
\text { encouragements to the adoption of a given innovation }\end{array}$ & Ifinedo (2011) \\
\hline Size & $\begin{array}{l}\text { Larger firms tend to possess slack resources that assist in the adoption of new technologies, and } \\
\text { are prone to reaching economies of scale and, due to their internal structure and organization, } \\
\text { have a significant capacity to undertake bigger risks. }\end{array}$ & Hsu et al. (2006), Liang et al. (2007) \\
\hline Standards Uncertainty & $\begin{array}{l}\text { Standards uncertainty refers to the extent of incapacity to estimate whether SNS will remain } \\
\text { stable and will be able to deliver the results that were initially defined }\end{array}$ & Venkatesh and Bala (2012) \\
\hline Technology Readiness & $\begin{array}{l}\text { The existence of both a technology infrastructure and qualified IT human resources to enable } \\
\text { and foster Internet-related business activities may provide some influence in the SNS adoption } \\
\text { process }\end{array}$ & Zhu et al. (2006) \\
\hline $\begin{array}{l}\text { Top Management } \\
\text { Belief }\end{array}$ & $\begin{array}{l}\text { The top management belief construct refers to the firm's top managers' beliefs toward the } \\
\text { benefits and potential of SNS }\end{array}$ & Liang et al. (2007) \\
\hline $\begin{array}{l}\text { Top Management } \\
\text { Participation }\end{array}$ & $\begin{array}{l}\text { Top management participation refers to the behaviours and actions taken by the firm's top } \\
\text { managers in order to facilitate the SNS assimilation process }\end{array}$ & Liang et al. (2007) \\
\hline $\begin{array}{l}\text { Top Management } \\
\text { Support }\end{array}$ & $\begin{array}{l}\text { Top management support will help focus efforts toward the creation of awareness of the } \\
\text { organizational benefits of adopting SNS and lends credibility to the implementation and use of } \\
\text { this technology }\end{array}$ & Wang et al. (2010) \\
\hline $\begin{array}{l}\text { Trust in SNS } \\
\text { Participants }\end{array}$ & $\begin{array}{l}\text { The trust in SNS participants construct refers to the perceived notion of dependability, } \\
\text { reliability, honesty, and trustworthiness placed by firms in other SNS participants such as } \\
\text { suppliers or enquirers }\end{array}$ & Messerschmidt and Hinz (2013) \\
\hline $\begin{array}{l}\text { Trust in SNS } \\
\text { Technology }\end{array}$ & $\begin{array}{l}\text { For the purpose of this project, we characterized trust as the expectation that an actor will be } \\
\text { reliable, predictable, and fair. For the purpose of studying the adoption of SNS at firm level, we } \\
\text { defined two separate dimensions for trust: (1) firms can trust SNS and (2) firms can trust other } \\
\text { SNS users }\end{array}$ & Messerschmidt and Hinz (2013) \\
\hline $\begin{array}{l}\text { Unresolved Technical } \\
\text { Issues }\end{array}$ & $\begin{array}{l}\text { The unresolved technical issues construct refers to the set of technology characteristics and } \\
\text { issues that are not within the firm's control (Ex.: security and data protection issues, the lack of } \\
\text { adequate payments systems, the inexistence of a reliable and robust technology infrastructure, } \\
\text { etc.) }\end{array}$ & Teo et al. (2006) \\
\hline $\begin{array}{l}\text { Use of SNS for } \\
\text { Competitive } \\
\text { Advantage }\end{array}$ & $\begin{array}{l}\text { The use of SNS for competitive advantage refers to the extent to which a firm plans and } \\
\text { implements SNS investments to enhance organizational competitive advantages as a proxy for } \\
\text { organizational performance }\end{array}$ & Kearns and Lederer (2004) \\
\hline
\end{tabular}


Table 4

Delphi study overall results.

\begin{tabular}{|c|c|c|c|c|}
\hline Variables & $\begin{array}{l}\text { Initial } \\
\text { Position }\end{array}$ & $\begin{array}{l}\text { Round } \\
1\end{array}$ & $\begin{array}{l}\text { Round } \\
2\end{array}$ & $\begin{array}{l}\text { Round } 2 \text { RI } \\
\text { Avg }\end{array}$ \\
\hline Need for Privacy & 12 & 1 & 1 & 5.89 \\
\hline $\begin{array}{l}\text { Alignment of SNS Plan with } \\
\text { Business Plan }\end{array}$ & 1 & 2 & 2 & 5.83 \\
\hline Top Management Belief & 21 & 3 & 3 & 5.83 \\
\hline $\begin{array}{l}\text { Use of SNS for Competitive } \\
\text { Advantage }\end{array}$ & 27 & 5 & 4 & 5.78 \\
\hline Competitive Pressure & 5 & 4 & 5 & 5.61 \\
\hline Top Management Support & 23 & 9 & 6 & 5.44 \\
\hline Trust in SNS Participants & 24 & 8 & 7 & 5.22 \\
\hline $\begin{array}{l}\text { Top Management } \\
\text { Participation }\end{array}$ & 22 & 10 & 8 & 5.17 \\
\hline IT Participation in Business & 9 & 6 & 9 & 5.06 \\
\hline Readiness & 15 & 14 & 10 & 5.00 \\
\hline Coercive Pressures & 3 & 13 & 11 & 4.78 \\
\hline Regulatory Concerns & 16 & 15 & 12 & 4.67 \\
\hline Relative Advantage & 17 & 16 & 13 & 4.67 \\
\hline Perceived Industry Pressure & 14 & 11 & 15 & 4.56 \\
\hline Technology Readiness & 20 & 17 & 16 & 4.56 \\
\hline Unresolved Technical Issues & 26 & 7 & 14 & 4.56 \\
\hline Compatibility & 4 & 12 & 17 & 4.50 \\
\hline Trust in SNS Technology & 25 & 19 & 18 & 4.50 \\
\hline Business Dependence on IT & 2 & 20 & 19 & 4.44 \\
\hline Mimetic Pressures & 11 & 18 & 20 & 4.39 \\
\hline Normative Pressures & 13 & 22 & 21 & 4.22 \\
\hline Lack of Interoperability & 10 & 21 & 22 & 4.17 \\
\hline Government Pressure & 8 & 24 & 23 & 3.83 \\
\hline Size & 18 & 25 & 24 & 3.83 \\
\hline Complexity & 6 & 26 & 25 & 3.56 \\
\hline Globalization Level & 7 & 27 & 26 & 3.50 \\
\hline Standards Uncertainty & 19 & 23 & 27 & 3.44 \\
\hline
\end{tabular}

variable RI (using a numeric scale of 7 points). Ten variables that were considered as the most important in the adoption of SNS at firm level emerged from the results of the average RI value in the second round of the study.

\subsection{Stage 2 - research model}

The Delphi study resulted in a set of ten variables which, according to a set of experts, were those that would have the greatest impact on the adoption of social network sites by firms. In accordance with the (mixed) methodology that underpinned the entire project, once the qualitative study was finished, a quantitative approach was to be executed. With this mind a research model (Fig. 1), that characterizes the adoption of SNS at firm level, was designed and an empirical study that could validate it was planned and executed.

The proposed model represents eight hypotheses the concern eight individual variables/constructs grouped according to their scope in four different contexts: (1) top management, (2) security \& privacy, (3) organization, and (4) environment. As Table 5 shows, the research model variables are from different types and various sources. The "Top management" is a second order construct, reflective-reflective type, i.e., the reflective second order construct (top management) is composed of three first order reflective subconstructs (top management support, top management participation, and top management belief). Despite this composition, top management accounts for only hypothesis H1. "Readiness" is a second order construct, reflective formative type, composed of three first order reflective constructs (financial resources, IT sophistication, and trading partner readiness). These three variables form the second order formative construct that is "Readiness". This variable is the support for hypothesis H5. As for the remaining variables, they are all reflective and represent the remaining six hypotheses.

\subsubsection{Top management context}

The information systems and technologies literature that exists at present regards top management actions and perceptions as important factors for the success of IS/IT supported business initiatives (Bassellier and Pinsonneault, 1998; Doll, 1985; Nolan and McFarlan, 2005). As argued by Xu and Quaddus (2012), today's business environment forces top managers to support, in every way they can, the adoption of new technologies as a means to maintain the necessary competitiveness. The merger of SNS features with Young and Jordan (2008) and Wang et al. (2010) perception of the top management concept (a parallel combination of top management support toward investing, wanting to take risks, and thriving on achieving competitive advantages, top management active participation in the definition of SNS related business visions, strategies and goals, and top management belief that the adoption of social network sites will benefit the organization and enhance its competitiveness) allowed us to hypothesize on top management positive triggers for SNS adoption. The top management construct is composed of three sub-constructs: top management support, top management participation, and top management belief. Hence:

H1. Top management perspective and actions toward SNS represent a positive argument for its adoption at firm level.

\subsubsection{Security and privacy context}

According to Messerschmidt and Hinz (2013), if a company perceives those who are supplying and using a given technology as reliable, honest, and trustworthy, the adoption process of that technology will be significantly improved and the possibilities of success will increase. This issue is a great concern for companies because they tend to be uneasy when their collaborators use a given technology on behalf of the company (Benbasat and Wang, 2005). The level of trust in those using social networks sites on their own behalf or on behalf of an organization is, according to Kietzmann et al. (2011) and Laroche et al. (2012), an important factor to the SNS adoption process. When looking at these technologies' main features, one can easily understand that the creation of virtual profiles for individuals or organizations and the use of that same profile for inappropriate purposes represent simple tasks that might have a significant impact, especially on organizations that do not need the extra aggravation of exposing themselves to (another) unreliable context (Sherchan et al., 2013). With this in mind, for the present research our interpretation of trust will represent the organization's expectation that a given actor can perform reliable work and act ethically and with a fair amount of honesty when using SNS, for both personal and organizational purposes (Chong et al., 2009). By understanding the innovative and interactive nature of social networks sites, and combining these with the existing literature on the influence trust issues have on IT adoption, we hypothesize the following:

H2. The existence of trust in those who use SNS represents a positive indicator for the adoption of these technologies at firm level.

According to Smith et al. (2011) and Messerschmidt and Hinz (2013), one of the most important concerns associated with Web based technologies are those related with data privacy. Besides this, at firm level the competitors' awareness of the intensity level or the planning and execution of business initiatives supported by a given technology, represent critical issues regarding the maintenance of competiveness levels, as well as the full adoption of those same technologies (Hung et al., 2007). SNS are technologies that embrace several features developed to trigger the establishment of relationships, the sharing of content with communities of interest, and the enrolment of simultaneous multi-user communication 


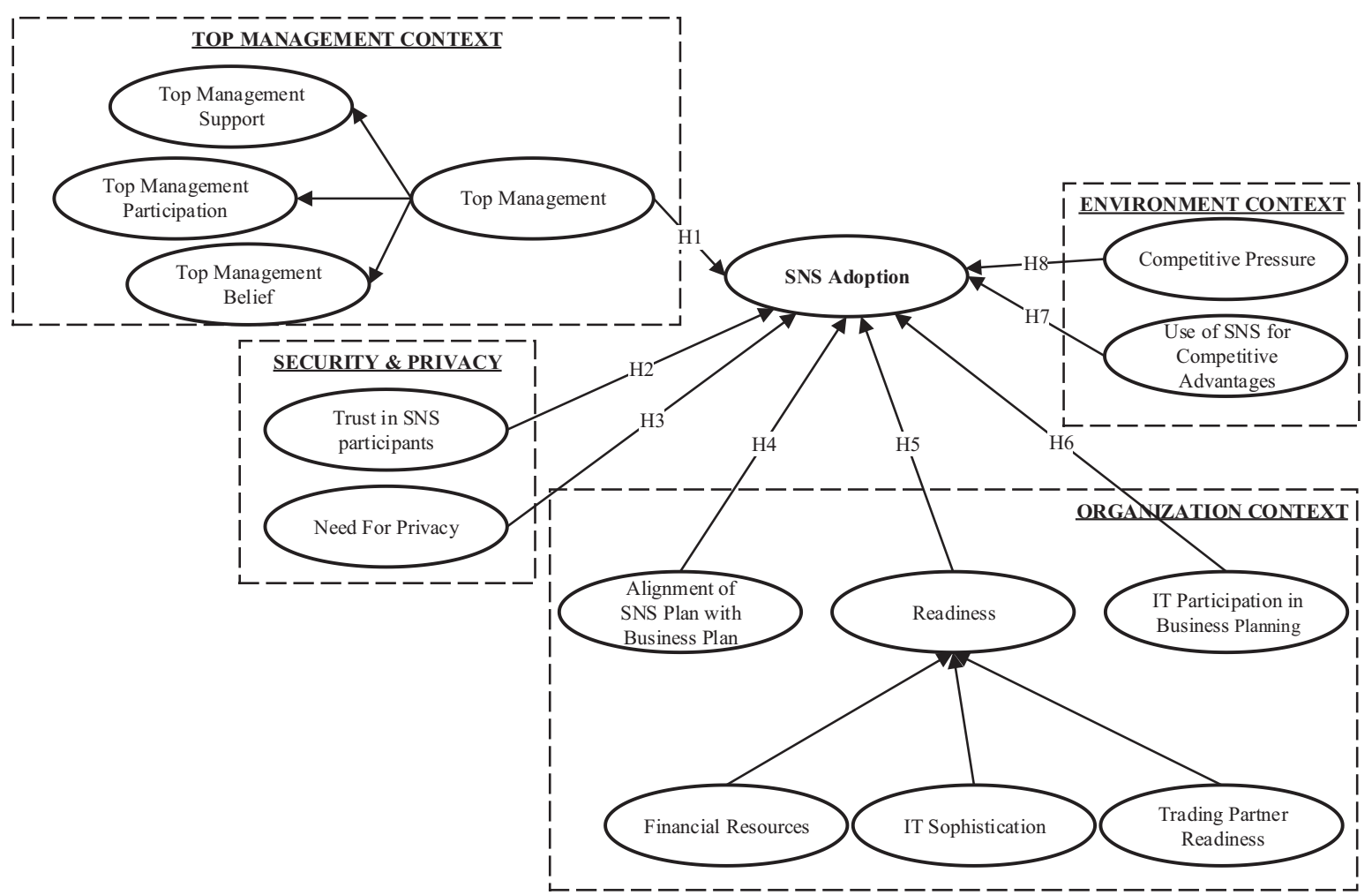

Fig. 1. Research model for characterizing SNS adoption at firm level.

Table 5

Sources of measurement variables.

\begin{tabular}{|c|c|c|c|c|c|}
\hline Variable & Type & Sub-variable & Type & Source & Items \\
\hline \multirow[t]{3}{*}{ Top Management } & \multirow[t]{3}{*}{ Reflective } & Top management support & Reflective & Wang et al. (2010) & 4 \\
\hline & & Top management participation & Reflective & Liang et al. (2007) & 3 \\
\hline & & Top management belief & Reflective & Liang et al. (2007) & 3 \\
\hline Trust in SNS participants & Reflective & - & - & Messerschmidt and Hinz (2013) & 4 \\
\hline Need for privacy & Reflective & - & - & Messerschmidt and Hinz (2013) & 2 \\
\hline Alignment of SNS plan with business plan & Reflective & - & - & Kearns and Lederer (2004) & 5 \\
\hline \multirow[t]{3}{*}{ Readiness } & \multirow[t]{3}{*}{ Formative } & Financial resources & Reflective & Chwelos et al. (2001) & 3 \\
\hline & & IT sophistication & Reflective & Chwelos et al. (2001) & 7 \\
\hline & & Trading partner readiness & Reflective & Chwelos et al. (2001) & 8 \\
\hline IT participation in business planning & Reflective & - & - & Kearns and Lederer (2004) & 5 \\
\hline Use of SNS for competitive advantages & Reflective & - & - & Kearns and Lederer (2004) & 4 \\
\hline Competitive pressure & Reflective & - & - & Ifinedo (2011) & 3 \\
\hline
\end{tabular}

processes (Leonardi et al., 2013). When combining these features with Claypoolle (2014) and Moorhead et al. (2013) assumptions on how social networks sites do not grant an absolute privacy of all data and on how important this issue is for organizations that might want to interact, in a more private manner with their customers or business partners, the following hypothesis arises:

H3. The need for privacy will diminish firm's intent to adopt SNS.

\subsubsection{Organization context}

As Web technology transforms itself as the result of constant technological and functional innovation, the management paradigms that are considered to be traditional are also being challenged and forced to adapt and ensure the alignment between the business strategy and the technology supported business initiatives (Byrd et al., 2006; Martins et al., 2014; Scheepers and Scheepers, 2008). According to Pereira et al. (2014), the implementation of business initiatives supported by IST must ensure the existence of alignment between the adopted technology and busi- ness model that drives the organizations, as this alignment will aid the resources optimization and performance. With this in mind and assuming SNS as a complex IST in which firms do not have significant know-how, in order for firms to be able to seize the advantages of SNS, they need to create mechanisms that allow for a proper definition (and inherent maintenance) of an alignment between the business strategies and the strategies for SNS adoption (Reich and Benbasat, 2013). This leads to the formulation of the following hypothesis:

H4. The existence of an alignment between the SNS strategic plan and the firm's overall strategic plan will foster the adoption of these technologies.

The literature indicates that a firm's readiness involves the existence of sufficient levels of availability, specialization and sophistication in terms of IS/IT, and the existence of enough financial resources for the necessary investments associated with a given technology adoption process (Iacovou et al., 1995). In order to formalize this assumption Chwelos et al. (2001) defined "Readiness" as a construct "composed of three sub-constructs: financial resources, IT sophistication (internal constructs encapsulating 
organizational readiness), and trading partner readiness (external)". Even though social networks sites are mostly free to use, and from the perspective of many scholars such as Baird and Parasnis (2011) and Hanna et al. (2011), the implementation of successful SNS related business initiatives depends on the existence of an effective strategy for supporting SNS related business initiatives, and on the need for a certain degree of resources (specialized HR, modern IT equipment, and financial resources to pay for the creation of highly attractive content that can foster customer engagement). On a similar note, the IT sophistication necessary for the implementation of the initiatives, and the readiness from the firm business partners will also play an important role in the success of the firms SNS adoption. Bearing in mind all of the above arguments, the following hypothesis was drawn:

H5. Considerable levels of organizational readiness will foster the adoption of SNS at firm level.

With the evolution of information systems and technologies, the information that is created, absorbed, and managed has become a very important resource for organizations and one that requires constant management (Kearns and Lederer, 2004), leading to the greater importance of IS/IT managers for firms, to the point of giving these collaborators a seat on decision making meetings (Kearns and Lederer, 2003; van den Hooff and de Winter, 2011). According to Mirchandani and Lederer (2012) and Zafar et al. (2015), in order for a given technology to be properly adopted and its use evolve to a degree of routinization, there must be deeper knowledge about that technology at the management level. This can exist only if the organization CIO becomes an active part of the decision making process. On a similar note, VaughanNichols (2010) and ITPRO (2014) claim that despite being considered technologies that are simple to use, the technological complexity behind each SNS is indeed significant and the organization's decision making teams should have the technical expertise and awareness on how SNS work in order for their decisions to be made in an informed and supported manner. Hence:

H6. The participation of IS/IT managers in the management and decision making processes will act as a trigger for SNS adoption at firm level.

\subsubsection{Environment context}

Constant use of IT comes about not only from the need to create mechanisms that support a quicker and more effective answer to firms daily challenges, but also as a means to maintain a level of performance and competitiveness compatible with the firm's business strategy (Cragg et al., 2002). As discussed by Kaplan and Haenlein (2010) and Kietzmann et al. (2011), social network sites currently represent very considerable new business opportunities and challenges, mainly as a result of these technologies' ability to, in a non-formal manner, bring firms and their customers closer together with a considerable degree of confidence and trust. Concerning the present research, the concept of adopting SNS as a trigger for the capture of competitive advantages is analysed from an organization performance point of view, as indicated by Kearns and Lederer (2004). Hence:

H7. The assumption that using SNS will create competitive advantages represents a positive variable in the adoption of these technologies at firm level.

The constant changes and transformations of the economic environment in which firms work are, most often, the triggers for competitiveness and performance needs that otherwise would not exist (Jeyaraj et al., 2006). According to Wang et al. (2010), this market instability creates a competitive environment that imposes pressures on companies that force them to constantly adapt to the new realities. These pressures are not applied only by those who see themselves as competitors, but also by business partners and especially by firms' customers. As pressure intensity increases, firms tend to search for new ways to generate value by adopting new technologies that may help to maintain their competitiveness level (Ifinedo, 2011). The sheer combination of the innovative features presented by SNS with the number of active users (according to Fang et al. (2013) over 1 billion), has led firms to direct their full attention to the adoption process and to the achievable possibilities. As firms start to adopt and use SNS, a competitive pressure starts to arise, forcing those firms that still have not adopted it, to exert a great deal of effort to start using. Considering the goal of the current research, the following hypothesis is advanced in order to assess the importance that competitive pressures will have in the SNS adoption process:

H8. The existence of competitive pressures will represent a positive influence on the SNS adoption at firm level.

\section{Empirical study}

\subsection{Measurement}

The validation of the variables that compose the proposed SNS adoption model in the current research was made through a questionnaire directed to Portuguese firms. This questionnaire was supported by the literature on the topics of IS/IT and technology adoption models (Appendix A).

In order to ensure coherence and integrity, the variables were measured on a quantitative scale of seven points going from "totally disagree" to "totally agree". The size of the firm was taken into consideration (number of employees and business volume), as was the business sector, these two variable were used as control variables (Chwelos et al., 2001; Premkumar and Roberts, 1999).

Prior to the public release of the questionnaire, a pilot study was made in order to ensure its validity and feasibility. In this initial study 30 firms were involved (results are not included in the final sample). The results indicate that all scales are valid and reliable, and that the questionnaire is effective as a mechanism for measuring the quality of the proposed model as a characterizer of the adoption of SNS at firm level.

\subsection{Data}

This research used as target group a list of Portuguese firms supplied by the Portuguese Agency for Innovation and Competitiveness with whom they have institutional relations and that use the Internet as a means to expand and support their business activities. After an initial analysis of the list and a manual validation of their current activity, 1389 firms were identified. The questionnaire was addressed to the firms' collaborators with the most experience with SNS or with Web related technologies and business initiatives (Alam et al., 2011) in order to ensure the greatest possible reliability of achieved results. In order to ensure that those who would answer the questionnaire understood exactly the SNS concept adopted, a brief and focused description of the social network sites concept was also included on the invitation that was sent via e-mail (Oliveira et al., 2014).

To decrease the risk of bias, the respondents to the questionnaire answered from a personal point-of-view and not from a firm's perspective. The research team decided to release the questionnaire results to those who answered, highlighting their response position vis-à-vis the overall sample. 
Appendix A

\begin{tabular}{|c|c|c|c|}
\hline Variables & & Items & Author(s) \\
\hline \multirow[t]{7}{*}{ Top management } & \multirow[t]{5}{*}{ Top management support } & $\begin{array}{l}\text { Using a seven-point scale where } 1 \text { is "strongly disagree" and } 7 \text { is "strongly agree", } \\
\text { please rate the following: }\end{array}$ & \multirow[t]{5}{*}{$\begin{array}{l}\text { Wang et al. } \\
(2010)\end{array}$} \\
\hline & & TMS1. My top management is likely to invest funds in SNS & \\
\hline & & TMS2. My top management is willing to take risks involved in the adoption of the SNS & \\
\hline & & $\begin{array}{l}\text { TMS3. My top management is likely to be interested in adopting SNS in order to gain } \\
\text { competitive advantage }\end{array}$ & \\
\hline & & $\begin{array}{l}\text { TMS4. My top management is likely to consider the adoption of the SNS as } \\
\text { strategically important }\end{array}$ & \\
\hline & $\begin{array}{l}\text { Top management } \\
\text { participation }\end{array}$ & $\begin{array}{l}\text { Using a seven-point scale where } 1 \text { is "strongly disagree" and } 7 \text { is "strongly agree", } \\
\text { please rate the following items concerning your firm top managers active actions: } \\
\text { TMP1. Articulates a vision for the organizational use of SNS } \\
\text { TMP2. Formulated a strategy for the organizational use of SNS } \\
\text { TMP3. Established goals and standards to monitor the ERP project }\end{array}$ & $\begin{array}{l}\text { Liang et al. } \\
\text { (2007) }\end{array}$ \\
\hline & \multirow[t]{2}{*}{ Top management belief } & $\begin{array}{l}\text { Using a seven-point scale where } 1 \text { is "strongly disagree" and } 7 \text { is "strongly agree", } \\
\text { please rate the following items concerning the beliefs of your firm top manager: } \\
\text { TMB1. SNS has the potential to provide significant business benefits to the firm } \\
\text { TMB2. SNS will create a significant competitive arena for firms. } \\
\text { TMB3. It is not necessary to use SNS to conduct business activities* }\end{array}$ & $\begin{array}{l}\text { Liang et al. } \\
(2007)\end{array}$ \\
\hline Trust in SNS participants & & $\begin{array}{l}\text { Using a seven-point scale where } 1 \text { is "strongly disagree" and } 7 \text { is "strongly agree", } \\
\text { please rate the following items related to SNS participants. In a general manner they } \\
\text { are: } \\
\text { TPart } 1 \text {. Dependable } \\
\text { TPart } 2 \text {. Reliable } \\
\text { TPart } 3 \text {. Honest } \\
\text { TPart } 4 \text {. Trustworthy }\end{array}$ & $\begin{array}{l}\text { Messerschmidt } \\
\text { and Hinz (2013) }\end{array}$ \\
\hline Need for Privacy & & $\begin{array}{l}\text { Using a seven-point scale where } 1 \text { is "strongly disagree" and } 7 \text { is "strongly agree", } \\
\text { please rate the following: }\end{array}$ & $\begin{array}{l}\text { Messerschmidt } \\
\text { and Hinz (2013) }\end{array}$ \\
\hline
\end{tabular}

Alignment of SNS Plan With Business Plan

Financial Resources

IT sophistication

Trading partner readiness

IT participation in business planning
NPR1. It is important that other firms in the SNS cannot discover at which time our firm is using resources in the SNS

NPR2. It is important that other firms in the SNS cannot discover how intensely our firm is using resources in the SNS

Using a seven-point scale where 1 is "strongly disagree" and 7 is "strongly agree", please rate the following:

APBP1. The SNS plan reflects the business plan mission

APBP2. The SNS plan reflects the business plan goals

APBP3. The SNS plan supports the business strategies

APBP4. The SNS plan recognizes external business environment forces

APBP5. The SNS plan reflects the business plan resource constraints

Using a seven-point scale where 1 is "not at all significant" and 7 is "extremely significant", please answer the following question:

FR1. In the context of your organization's overall Information Systems budget, how significant would be the financial cost of developing and implementing a solution including SNS?

FR2. Approximately how many people are employed in your firm?*

FR3. What was the (approximate) total revenue of your firm last year? (For non-profit firms, indicate total operating budget.) $)^{*}$

Using a seven-point scale where 1 is "not at all important" and 7 is "extremely important", please rate to the extent to which SNS are important for the fulfilment of the following objectives in your firm?

ITS1. Personnel Reduction

ITS2. Operational Costs Reduction

ITS3. Productivity Improvements

ITS4. Improved Access to Information*

ITS5. Improved Quality of Decision Making

ITS6. Improved Competitiveness

ITS7. Improved Service to Customers

Using a seven-point scale where 1 is "not at all important" and 7 is "extremely important", please rate the extent to which each of these factors would inhibit the adoption of SNS at your firm?

TPR1. Trading Partner Reluctance to Change

TPR2. Lack of Trust in Trading Partner(s)

TPR3. Training or Educating Trading Partner(s)

TPR4. Non-Automated/Non-Sophisticated Trading Partner(s)

TPR5. Poor Reputation of Trading Partner(s)

TPR6. Lack of Adequate Accounting or Legal Controls

TPR7. Inadequate Trading Volume to Justify SNS

TPR8. Difficulty in Achieving "Critical Mass" of Trading Partners

Using a seven-point scale where 1 is "strongly disagree" and 7 is "strongly agree", please rate the following:

ITPBP1. The IT executive regularly attends business planning meetings

ITPBP2. The IT executive contributes to the formulation of business goals

ITPBP3. The IS executive has regular informal contacts with top management

ITPBP4. The IT executive has easy access to the CEO

ITPBP5. The IT executive has frequent contacts with the CEO

\section{and Hinz (2013)}

Kearns and

Lederer (2004)

Chwelos et al. (2001)

Chwelos et al. (2001)

Chwelos et al. (2001)

Kearns and Lederer (2004) 
Appendix A (continued)

\begin{tabular}{|c|c|c|}
\hline Variables & Items & Author(s) \\
\hline Use of SNS for competitive advantage & $\begin{array}{l}\text { Using a seven-point scale where } 1 \text { is "strongly disagree" and } 7 \text { is "strongly agree", with } \\
\text { respect to your firm's core products or services and major customers and suppliers, } \\
\text { SNS has been used to: } \\
\text { UCA1. Provide advantages such as lower costs or product differentiation } \\
\text { UCA2. Establish electronic links with suppliers or customers } \\
\text { UCA3. Create barriers to keep competitors from entering our markets* } \\
\text { UCA4. Influence the buyer's decision to switch to our products } \\
\text { UCA5. Leverage unique firm capabilities }\end{array}$ & $\begin{array}{l}\text { Kearns and } \\
\text { Lederer (2004) }\end{array}$ \\
\hline Competitive pressure & $\begin{array}{l}\text { Using a seven-point scale where } 1 \text { is "strongly disagree" and } 7 \text { is "strongly agree", } \\
\text { please rate the following items: } \\
\text { CPR1. Our firm is under pressure from competitors to adopt SNS } \\
\text { CPR2. Some of our competitors have already started using SNS } \\
\text { CPR3. Our competitors know the importance of SNS and are using them for operations }\end{array}$ & Ifinedo (2011) \\
\hline SNS adoption & $\begin{array}{l}\text { Please select the applications of SNS in your value chain processes (select as many as } \\
\text { apply): } \\
\text { SNSA1. Advertising and marketing } \\
\text { SNSA2. Making sales online } \\
\text { SNSA3. After sales services and support }\end{array}$ & $\begin{array}{l}\text { Zhu et al. } \\
\text { (2006) }\end{array}$ \\
\hline
\end{tabular}

Note: "TMB3, FR2, FR3, and UCA3 question-items were excluded after PLS model estimation due to low loadings.

Despite the efforts to reach all of the firms to whom the questionnaire was directed, after the first batch of e-mails containing the information on the location of the survey and the instructions on how to respond to it, only 139 of the initial 1389 firms provided a valid response. Given the need for a more significant number of valid answers, a second batch of e-mails was sent to those firms that had not responded. This action led to the collection of another 108 valid responses, for a total of 247 . This amounted to $17.8 \%$ of the initial sample, which can be characterized as valid when compared with similar works (Hsu et al., 2006; Lin and Lin, 2008; Liu et al., 2008; Oliveira and Dhillon, 2015; Ranganathan et al., 2004; Ruivo et al., 2014).

Although various efforts have been undertaken to prevent inconsistent or invalid results, after collecting the data, the research team conducted tests to evaluate the possible existence of nonresponse bias between the early and late respondent groups. For this purpose we used a Kolmogorov-Smirnov test (Oliveira et al., 2014; Ryans, 1974), which revealed no statistical difference between early and late responses. In order to rule out the existence of common method bias, the research team carried out a Harman factor test (Podsakoff et al., 2003), according to which no bias was present.

\section{Results}

In order to test the proposed research model we used structural equation models (SEM). More specifically, partial least squares (PLS) was used for three main reasons: (i) most items were not normally distributed ( $p<0.01$ based on Kolmogorov-Smirnov's test); (ii) the conceptual model is considered complex; and (iii) the model has not been earlier tested. Smart PLS 2.0 M3 software was used to estimate the research model.

In the next two sections we examine respectively the measurement model and the structural model.

\subsection{Measurement model}

In the measurement model we evaluate the reflective (all constructs except readiness) and formative (readiness) constructs. For reflective constructs we assess indicator reliability, internal consistency, convergent validity, and discriminant validity. Construct reliability was tested using the composite reliability (CR) coefficient. As shown in Table 6, all the constructs have a CR above 0.7, which suggests that the constructs are reliable (Straub, 1989).

Table 6

Descriptive statistics, correlation, and square root of the AVE.

\begin{tabular}{|c|c|c|c|c|c|c|c|c|c|c|c|c|c|c|c|c|c|}
\hline Variables & Mean & S.D. & $\mathrm{CR}$ & TMS & TMP & TMB & TM & TPart & NPR & APBP & FR & ITS & TPR & ITPBP & UCA & CompP & SNSA \\
\hline $\begin{array}{l}\text { Top Management Support } \\
\text { (TMS) }\end{array}$ & 4.26 & 1.66 & 0.96 & 0.93 & & & & & & & & & & & & & \\
\hline $\begin{array}{l}\text { Top Management } \\
\text { Participation (TMP) }\end{array}$ & 4.28 & 1.72 & 0.98 & 0.81 & 0.97 & & & & & & & & & & & & \\
\hline Top Management Belief (TMB) & 4.57 & 1.67 & 0.97 & 0.81 & 0.79 & 0.97 & & & & & & & & & & & \\
\hline Top Management (TM) & 4.34 & 1.57 & 0.97 & 0.95 & 0.93 & 0.91 & 0.89 & & & & & & & & & & \\
\hline $\begin{array}{l}\text { Trust in SNS Participants } \\
\text { (TPart) }\end{array}$ & 4.65 & 1.14 & 0.98 & 0.31 & 0.33 & 0.35 & 0.35 & 0.97 & & & & & & & & & \\
\hline Need for Privacy (NPR) & 3.35 & 1.60 & 0.95 & -0.11 & -0.01 & 0.00 & -0.06 & 0.09 & 0.95 & & & & & & & & \\
\hline $\begin{array}{l}\text { Alignment of SNS Plan With } \\
\text { Business Plan (APBP) }\end{array}$ & 4.25 & 1.50 & 0.96 & 0.66 & 0.71 & 0.67 & 0.73 & 0.43 & 0.00 & 0.92 & & & & & & & \\
\hline Financial Resources (FR) & 3.75 & 1.49 & 1.00 & 0.32 & 0.25 & 0.32 & 0.31 & 0.30 & 0.06 & 0.30 & na & & & & & & \\
\hline IT Sophistication (ITS) & 3.67 & 1.40 & 0.91 & 0.53 & 0.48 & 0.55 & 0.55 & 0.26 & 0.07 & 0.53 & 0.39 & 0.79 & & & & & \\
\hline $\begin{array}{l}\text { Trading Partner Readiness } \\
\quad \text { (TPR) }\end{array}$ & 3.76 & 1.24 & 0.92 & 0.07 & 0.09 & 0.11 & 0.09 & 0.05 & 0.28 & 0.11 & 0.18 & 0.33 & 0.77 & & & & \\
\hline $\begin{array}{l}\text { IT Participation in Business } \\
\text { Planning (ITPBP) }\end{array}$ & 4.92 & 1.56 & 0.94 & 0.36 & 0.42 & 0.40 & 0.42 & 0.33 & -0.02 & 0.46 & 0.16 & 0.12 & 0.01 & 0.88 & & & \\
\hline $\begin{array}{l}\text { Use of SNS for competitive } \\
\text { advantage (UCA) }\end{array}$ & 5.08 & 1.37 & 0.92 & 0.64 & 0.61 & 0.73 & 0.70 & 0.32 & -0.01 & 0.61 & 0.27 & 0.49 & 0.18 & 0.36 & 0.87 & & \\
\hline Competitive Pressure (CompP) & 3.96 & 1.59 & 0.92 & 0.66 & 0.55 & 0.59 & 0.65 & 0.22 & -0.01 & 0.44 & 0.37 & 0.50 & 0.11 & 0.20 & 0.57 & 0.89 & \\
\hline SNS Adoption (SNSA) & 3.76 & 1.76 & 0.92 & 0.74 & 0.69 & 0.69 & 0.76 & 0.24 & -0.03 & 0.60 & 0.22 & 0.58 & 0.12 & 0.27 & 0.63 & 0.65 & 0.89 \\
\hline
\end{tabular}

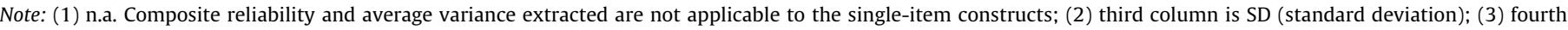
column is CR (composite reliability); (4) diagonal elements are the square root of average variance extracted (AVE) (in bold). 
The indicator reliability was evaluated based on the criteria that the loadings should be greater than 0.70 , and that every loading less than 0.4 should be eliminated (Churchill, 1979; Henseler et al., 2009). As a result, four items, TMB3, FR2, FR3, and UCA3, were eliminated. As seen in Table 7, the instrument presents good indicator reliability. In order to assess convergent validity, average variance extracted (AVE) was used. The AVE should be greater than 0.5 (Fornell and Larcker, 1981; Henseler et al., 2009). As also seen in Table 6, AVE for each construct is above the expected threshold of 0.5 , ensuring convergent validity. Finally, discriminant validity was tested based on two criteria: (i) the loadings are larger than cross loadings, is confirmed in Table 7; (ii) the square root of AVE for each construct should be greater than the correlations with all constructs (Fornell and Larcker, 1981). As we can see in Table 6, the square root of AVE (in bold) is higher than the correlation between constructs. The only exception is between the correlation of top management (TM) with top management support (TMS), top management participation (TMP), and top management belief (TMB). This was to be expected since "Top Management" corresponds a second order construct of "top management support (TMS)", "top management participation (TMP)", and "top management belief (TMB)". We conclude that all the constructs show evidence of acceptable discrimination.

For formative constructs we evaluate the multicollinearity and weights. In our model we have only one formative construct (readiness). Readiness is a second order construct that was modelled using three formative first order constructs. The test for multicollinearity was conducted based on variance inflation factor (VIF) values. VIF of Financial Resources (FR), IT sophistication (ITS), and trading partner readiness (TPR) are respectively 1.18, 1.27 , and 1.12 , and all present VIF values below 5. Collinearity therefore does not raise issues (Hair Jr et al., 2013). Outer weights of the readiness second order construct were statistically significant for all three first order constructs (Hair Jr et al., 2013).

Table 7

Loadings and cross-loadings.

\begin{tabular}{|c|c|c|c|c|c|c|c|c|c|c|c|c|c|c|}
\hline Items & TMS & TMP & TMB & TM & TPart & NPR & APBP & RFR & RITS & RTPR & ITPB & UCA & CompP & SNSA \\
\hline TMS1 & 0.88 & 0.72 & 0.70 & 0.84 & 0.26 & -0.05 & 0.59 & 0.34 & 0.48 & 0.11 & 0.26 & 0.52 & 0.50 & 0.66 \\
\hline TMS2 & 0.94 & 0.72 & 0.71 & 0.87 & 0.28 & -0.12 & 0.60 & 0.31 & 0.48 & 0.09 & 0.32 & 0.57 & 0.62 & 0.67 \\
\hline TMS3 & 0.95 & 0.77 & 0.78 & 0.91 & 0.31 & -0.13 & 0.63 & 0.27 & 0.50 & 0.03 & 0.37 & 0.65 & 0.66 & 0.70 \\
\hline TMS4 & 0.95 & 0.79 & 0.81 & 0.93 & 0.31 & -0.12 & 0.65 & 0.26 & 0.50 & 0.03 & 0.39 & 0.63 & 0.65 & 0.71 \\
\hline TMP1 & 0.80 & 0.97 & 0.78 & 0.91 & 0.31 & -0.05 & 0.71 & 0.23 & 0.48 & 0.09 & 0.39 & 0.62 & 0.54 & 0.70 \\
\hline TMP2 & 0.78 & 0.97 & 0.78 & 0.91 & 0.32 & 0.00 & 0.69 & 0.24 & 0.46 & 0.08 & 0.42 & 0.60 & 0.52 & 0.67 \\
\hline TMP3 & 0.75 & 0.96 & 0.73 & 0.87 & 0.34 & 0.02 & 0.67 & 0.26 & 0.45 & 0.10 & 0.40 & 0.55 & 0.54 & 0.62 \\
\hline TMB1 & 0.80 & 0.78 & 0.97 & 0.89 & 0.33 & -0.02 & 0.67 & 0.31 & 0.52 & 0.10 & 0.40 & 0.72 & 0.57 & 0.68 \\
\hline TMB2 & 0.77 & 0.76 & 0.97 & 0.87 & 0.35 & 0.02 & 0.63 & 0.30 & 0.56 & 0.12 & 0.38 & 0.70 & 0.57 & 0.67 \\
\hline TPart1 & 0.35 & 0.36 & 0.36 & 0.38 & 0.97 & 0.08 & 0.43 & 0.31 & 0.26 & 0.02 & 0.31 & 0.31 & 0.24 & 0.26 \\
\hline TPart2 & 0.29 & 0.31 & 0.33 & 0.33 & 0.96 & 0.10 & 0.41 & 0.29 & 0.25 & 0.07 & 0.30 & 0.33 & 0.22 & 0.23 \\
\hline TPart3 & 0.28 & 0.30 & 0.32 & 0.32 & 0.97 & 0.10 & 0.41 & 0.28 & 0.24 & 0.04 & 0.32 & 0.29 & 0.19 & 0.20 \\
\hline TPart4 & 0.29 & 0.32 & 0.32 & 0.33 & 0.97 & 0.09 & 0.43 & 0.27 & 0.25 & 0.04 & 0.34 & 0.29 & 0.20 & 0.23 \\
\hline NPR1 & -0.12 & -0.01 & 0.00 & -0.06 & 0.09 & 0.99 & -0.01 & 0.07 & 0.07 & 0.28 & -0.02 & -0.02 & -0.02 & -0.04 \\
\hline NPR2 & -0.09 & 0.00 & -0.01 & -0.05 & 0.08 & 0.91 & 0.02 & 0.04 & 0.07 & 0.24 & -0.01 & 0.01 & 0.05 & -0.01 \\
\hline APBP1 & 0.62 & 0.66 & 0.60 & 0.68 & 0.42 & 0.00 & 0.94 & 0.33 & 0.48 & 0.10 & 0.41 & 0.55 & 0.41 & 0.56 \\
\hline APBP2 & 0.63 & 0.68 & 0.61 & 0.69 & 0.41 & -0.02 & 0.96 & 0.29 & 0.50 & 0.07 & 0.44 & 0.59 & 0.42 & 0.58 \\
\hline АРBP3 & 0.64 & 0.67 & 0.61 & 0.69 & 0.43 & -0.03 & 0.95 & 0.30 & 0.51 & 0.08 & 0.42 & 0.58 & 0.42 & 0.55 \\
\hline APBP4 & 0.65 & 0.69 & 0.70 & 0.72 & 0.40 & 0.04 & 0.89 & 0.27 & 0.50 & 0.14 & 0.47 & 0.60 & 0.42 & 0.54 \\
\hline APBP5 & 0.50 & 0.56 & 0.54 & 0.57 & 0.32 & 0.01 & 0.84 & 0.19 & 0.43 & 0.14 & 0.37 & 0.49 & 0.34 & 0.52 \\
\hline FR1 & 0.32 & 0.25 & 0.32 & 0.31 & 0.30 & 0.06 & 0.30 & 1.00 & 0.39 & 0.18 & 0.16 & 0.27 & 0.37 & 0.22 \\
\hline ITS1 & 0.13 & 0.15 & 0.12 & 0.14 & 0.12 & 0.17 & 0.20 & 0.28 & 0.68 & 0.31 & -0.08 & 0.05 & 0.13 & 0.17 \\
\hline ITS2 & 0.37 & 0.33 & 0.40 & 0.39 & 0.19 & 0.00 & 0.41 & 0.30 & 0.79 & 0.18 & 0.04 & 0.28 & 0.34 & 0.43 \\
\hline ITS3 & 0.44 & 0.41 & 0.49 & 0.47 & 0.28 & 0.08 & 0.43 & 0.36 & 0.87 & 0.26 & 0.17 & 0.40 & 0.43 & 0.50 \\
\hline ITS5 & 0.44 & 0.38 & 0.43 & 0.45 & 0.20 & 0.11 & 0.44 & 0.33 & 0.85 & 0.33 & 0.11 & 0.35 & 0.42 & 0.50 \\
\hline ITS6 & 0.63 & 0.55 & 0.66 & 0.65 & 0.20 & -0.03 & 0.55 & 0.29 & 0.78 & 0.21 & 0.18 & 0.65 & 0.55 & 0.61 \\
\hline ITS8 & 0.47 & 0.43 & 0.50 & 0.50 & 0.21 & -0.02 & 0.47 & 0.26 & 0.75 & 0.26 & 0.14 & 0.55 & 0.46 & 0.51 \\
\hline TPR1 & 0.06 & 0.07 & 0.14 & 0.09 & 0.06 & 0.29 & 0.08 & 0.22 & 0.30 & 0.83 & 0.00 & 0.17 & 0.10 & 0.10 \\
\hline TPR2 & 0.11 & 0.12 & 0.13 & 0.12 & 0.05 & 0.25 & 0.12 & 0.17 & 0.38 & 0.88 & 0.00 & 0.17 & 0.18 & 0.19 \\
\hline TPR3 & 0.07 & 0.10 & 0.13 & 0.10 & 0.07 & 0.26 & 0.10 & 0.14 & 0.33 & 0.82 & 0.00 & 0.20 & 0.07 & 0.13 \\
\hline TPR4 & 0.13 & 0.10 & 0.15 & 0.14 & 0.06 & 0.16 & 0.16 & 0.15 & 0.30 & 0.85 & 0.03 & 0.22 & 0.10 & 0.13 \\
\hline TPR5 & 0.14 & 0.16 & 0.14 & 0.16 & -0.06 & 0.24 & 0.15 & 0.07 & 0.28 & 0.77 & 0.03 & 0.18 & 0.14 & 0.18 \\
\hline TPR6 & -0.08 & -0.04 & -0.07 & -0.07 & -0.04 & 0.21 & -0.02 & 0.06 & 0.09 & 0.70 & 0.00 & 0.03 & 0.02 & -0.02 \\
\hline TPR7 & -0.11 & -0.06 & -0.06 & -0.09 & 0.08 & 0.15 & -0.05 & 0.15 & 0.05 & 0.55 & -0.01 & -0.03 & -0.03 & -0.14 \\
\hline TPR8 & -0.04 & 0.01 & -0.02 & -0.02 & 0.07 & 0.13 & 0.07 & 0.16 & 0.14 & 0.67 & 0.01 & 0.04 & 0.01 & 0.00 \\
\hline ITPBP1 & 0.31 & 0.34 & 0.36 & 0.35 & 0.30 & 0.05 & 0.39 & 0.22 & 0.15 & 0.04 & 0.84 & 0.30 & 0.20 & 0.23 \\
\hline ITPBP2 & 0.31 & 0.37 & 0.38 & 0.37 & 0.25 & 0.02 & 0.40 & 0.17 & 0.16 & 0.00 & 0.85 & 0.28 & 0.20 & 0.24 \\
\hline ITPBP3 & 0.35 & 0.38 & 0.36 & 0.39 & 0.34 & -0.07 & 0.41 & 0.17 & 0.12 & 0.04 & 0.92 & 0.31 & 0.19 & 0.22 \\
\hline ITPBP4 & 0.33 & 0.39 & 0.33 & 0.38 & 0.29 & -0.08 & 0.42 & 0.10 & 0.07 & -0.01 & 0.88 & 0.35 & 0.17 & 0.26 \\
\hline ITPBP5 & 0.29 & 0.36 & 0.34 & 0.35 & 0.27 & -0.02 & 0.41 & 0.06 & 0.05 & -0.01 & 0.89 & 0.34 & 0.11 & 0.25 \\
\hline UCA1 & 0.54 & 0.55 & 0.65 & 0.61 & 0.31 & 0.06 & 0.59 & 0.27 & 0.52 & 0.17 & 0.25 & 0.82 & 0.51 & 0.58 \\
\hline UCA2 & 0.54 & 0.51 & 0.64 & 0.59 & 0.29 & -0.04 & 0.54 & 0.26 & 0.47 & 0.16 & 0.34 & 0.89 & 0.48 & 0.52 \\
\hline UCA4 & 0.57 & 0.52 & 0.62 & 0.60 & 0.24 & -0.04 & 0.48 & 0.21 & 0.37 & 0.18 & 0.31 & 0.89 & 0.49 & 0.55 \\
\hline UCA5 & 0.56 & 0.54 & 0.62 & 0.61 & 0.25 & -0.02 & 0.51 & 0.21 & 0.32 & 0.11 & 0.35 & 0.88 & 0.46 & 0.51 \\
\hline CompP1 & 0.51 & 0.44 & 0.42 & 0.50 & 0.07 & 0.04 & 0.34 & 0.30 & 0.48 & 0.19 & 0.12 & 0.39 & 0.81 & 0.58 \\
\hline CompP2 & 0.60 & 0.50 & 0.55 & 0.59 & 0.20 & -0.04 & 0.38 & 0.33 & 0.39 & 0.04 & 0.20 & 0.55 & 0.92 & 0.55 \\
\hline CompP3 & 0.63 & 0.53 & 0.59 & 0.63 & 0.30 & -0.03 & 0.44 & 0.34 & 0.46 & 0.06 & 0.20 & 0.56 & 0.93 & 0.58 \\
\hline SNSA1 & 0.68 & 0.63 & 0.61 & 0.69 & 0.22 & 0.02 & 0.54 & 0.17 & 0.41 & 0.06 & 0.25 & 0.48 & 0.55 & 0.84 \\
\hline SNSA2 & 0.67 & 0.63 & 0.65 & 0.70 & 0.22 & -0.08 & 0.54 & 0.26 & 0.58 & 0.13 & 0.23 & 0.61 & 0.61 & 0.93 \\
\hline SNSA3 & 0.64 & 0.58 & 0.60 & 0.65 & 0.20 & -0.02 & 0.53 & 0.15 & 0.57 & 0.13 & 0.25 & 0.59 & 0.57 & 0.91 \\
\hline
\end{tabular}

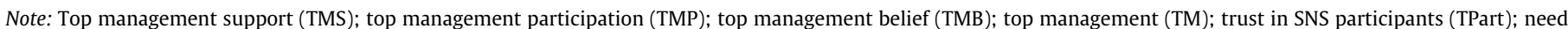

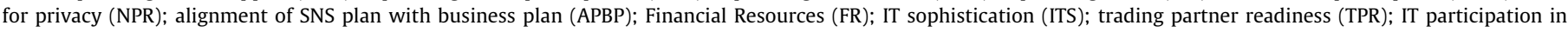
business planning (ITPBP); use of SNS for competitive advantage (UCA); competitive pressure (CompP); SNS adoption (SNSA). 
The evaluations of the construct reliability, indicator reliability, convergent validity, and discriminant validity for reflective constructs, and the multicollinearity and weights for formative constructs were adequate, indicating that the all constructs are suitable for testing the conceptual model.

\subsection{Structural model}

The hypotheses were examined for connections between the independent and dependent variables. The significance level of each connection was estimated using a bootstrapping method (5000 re-samples), configured to execute the necessary estimations based on 248 individuals. The results of this analysis are in Fig. 2. The conceptual model explains $65.5 \%$ of the variation in SNS adoption. It is possible to assume that it is adequate to characterize the adoption of these technologies at firm level. The top management $(\mathrm{H} 1)(\hat{\beta}=0.471, p<0.01)$, alignment of SNS plan with business plan (H4) $\hat{\beta}=0.100, p<0.10$ ), use of SNS for competitive advantage $(\mathrm{H} 7) \hat{\beta}=0.113, p<0.10$ ), and competitive pressure (H8) $\hat{\beta}=0.227, p<0.01$ ) are statistically significant.

In summary, hypotheses $\mathrm{H} 1, \mathrm{H} 4, \mathrm{H} 7$, and $\mathrm{H} 8$ are confirmed, while $\mathrm{H} 2, \mathrm{H} 3, \mathrm{H} 5$, and $\mathrm{H} 6$ are not confirmed. The external pressure context is the only context in which all hypotheses are confirmed.

\section{Discussion}

\subsection{Research implications}

Even though the results indicate that the proposed model might be considered representative of the SNS adoption at firm level, this representability depends mostly on four variables: (1) Top man- agement, (2) Alignment of SNS plan with business plan, (3) Use of SNS for competitive advantage, and (4) Competitive pressure (Fig. 2).

\subsubsection{Top management context}

This research provides strong evidence that in order to hold successful SNS related business initiatives, firms' top management must become fully involved with all business activities and processes $(\mathrm{H} 1)$, and with this create a perception that those initiatives are very important for the firms' business and that those directly associated with it must perform at the best of their abilities and with a sense of ethics and professionalism.

Our results are consistent with those of other studies that focused attention on the adoption of technology (Ifinedo, 2011; Luo et al., 2010) and indicate that top managers might enhance their influence to SNS adoption process if they believe in the technology's potential and associated opportunities, if they participate in the definition of strategies and goals for the business initiatives supported by SNS, if they support SNS adoption by raising and allocating financial and organizational resources, and by creating positive and proactive synergies.

\subsubsection{Security and privacy context}

Our results support the belief that the trust levels of those directly and indirectly involved with social networks sites should not be considered as a decisive factor for the adoption of the technologies under examination. Thus, hypothesis (H2) cannot be verified. This same conclusion pertains to hypothesis (H3), concerning the need for privacy as an inhibitor to SNS adoption. Although agreeing with the findings of other studies (Brandtzæg et al., 2010; Muñoz et al., 2012; Oliveira et al., 2014), our results indicate that even though firms have an awareness of existing trust issues

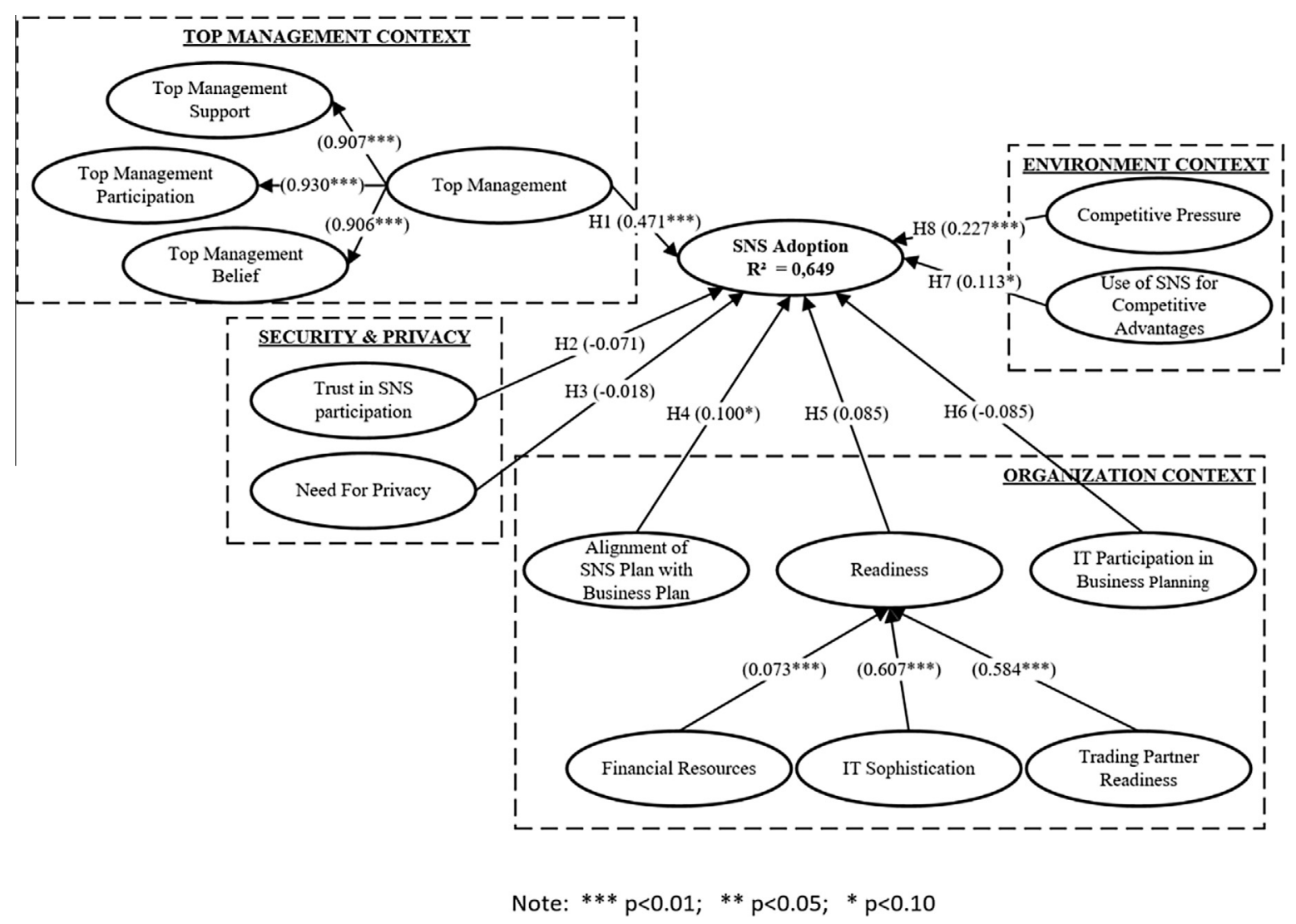

Fig. 2. Model that characterized the adoption of SNS at firm level. 
and the need for data and information privacy, their main concern resides with becoming part of the network and to start taking advantage of the technologies quickly, and thus accepting the existing level of public exposure and risk as a trade-off for being able to realize the business opportunities and benefits inherent with SNS.

\subsubsection{Organization context}

As indicated by the results, hypothesis ( $\mathrm{H} 4)$ was considered validated, and with this arises the need for firms to create mechanisms that guarantee alignment between the strategies behind SNS initiatives and firms' business plans. From a scientific perspective, this acknowledgement is in line with other similar published studies and highlights the importance of implementing SNS supported business initiatives that comply with firms' business goals and social and market positions (Kearns and Lederer, 2003, 2004; Reich and Benbasat, 2013). By considering the above, and drawing on Aversano et al. (2013), Pereira et al. (2014), when defining the strategies that will support successful SNS business initiatives, firms need to ensure that the strategic elements identified are aligned with the organizational objectives, limitations, and constraints.

The influence of firms' readiness level to the adoption of SNS (H5) could not be satisfactorily demonstrated by the research data, leading us to admit that even though the literature on Web technologies claims otherwise (Chwelos et al., 2001; Yoon and George, 2013), and after a careful analysis of this indicator (BenMark, 2014; Huy and Shipilov, 2012), the readiness issue is of reduced importance (BenMark, 2014; Huy and Shipilov, 2012). This belief derives from the findings that there is a significant decrease in the financial resources needed to support an SNS business initiative, when compared to those needed to support a different IT business initiative, as well as the technological simplicity inherent - not to the development and maintenance of SNS, but to the use of those technologies from a professional perspective and the rate at which firms' business partners are also gaining awareness and know-how on social networks sites.

Contingencies of modern times and economies have forced an evolution in human and technological skills that one must have to become a good CIO. Currently a director of IT/IS must not only be someone with a high technical knowledge on the organization's IT infrastructure and all existing information systems, but should also possess strong know-how on how the organization functions, on its surrounding environment, and on its overall strategy (Chen, 2010; Li et al., 2011). Despite the recognized importance of having the IT/IS department involved in the organization strategy definition and planning (H6), the data gathered in this study were not enough to empirically demonstrate that this is a reality regarding the adoption of social networks sites.

\subsubsection{Environment context}

The definition of SNS indicates that when correctly used, these technologies give organizations the opportunity to embrace a set of competitive advantages that may represent a very important asset when facing strongly competitive external markets. Drawing on this foundation, we undertook to empirically investigate if the possibility of achieving competitive advantages could impact the adoption of SNS by firms (H7). By analysing our results it was possible to observe, as Gorla et al. (2010) and Nevo and Wade (2011) claimed for other technologies, that the likelihood of existing competitive advantages associated with the adoption of SNS also impacts their adoption at the firm level. This observation may lead both firms and researchers to undertake activities seeking to improve their overall knowledge about what those competitive advantages are and how they can extract the most business value from them that is possible.
Analysing the existence of competitive pressures that may trigger SNS adoption by organizations (H7) was also a goal of this research. As already reported by other authors studying the adoption of other IT/IS related technologies (Chang et al., 2013; Chatterjee et al., 2002; Thomas et al., 2015), concerning the adoption of social networks sites at firm level, we confirm that the presence of competitive pressures positively impacts the adoption of SNS for business purposes. These pressures typically arise from the early adoption of SNS by competitors, which tends to create an erroneous perception that in order to maintain their competitive levels firms must imitate the rapid adoption of SNS, and the perception that competitors hold the knowledge about how to use SNS and are taking full advantage of their use.

\subsection{Theoretical and practical implications}

The existence of a knowledge gap concerning the adoption of social networks sites at firm level has led firms to plan and executive business initiatives supported by those technologies without a clear perception of how to do it nor how to measure its effects and return on investment. From our perspective, this study helps to fill this research gap through the construction and validation of a research model that characterizes $65 \%$ of the variation in SNS adoption at firm level and that identifies the influence on the adoption process of variables such as the alignment between IT strategies and business strategies, the top management (top management support, top management participation, top management belief), and the perspective of reaching competitive advantages by using SNS. This contribution will most certainly aid future researchers to draw indications and guidelines that might allow them to improve the proposed model or to achieve new ones that test the influence of other variables on the SNS adoption process at firm level.

From a theoretical perspective, the mixed methodology approach that was defined and the results achieved allow us to ensure that, as argued by several authors, this type of research methodology is adequate for studying the adoption of technologies at firm level. An extensive description of a wide set of variables identified in the existing scientific literature as influencing the technology adoption process is also included herein, thereby adding an interesting feature for future research in the technology adoption field.

The research reported here might also lead firms to improve their understanding of the determinants having the most influence in the SNS adoption process and, with this knowledge, improve their SNS supported business initiatives and better identify the associated metrics and how to evaluate them.

\subsection{Limitations and future works}

The research reported here has some limitations. Although a mixed methodology is recommended for information systems and technologies research projects, developing a Delphi study as the qualitative stage is not free of concerns. The arguments presented by Marques et al. (2011) and Paré et al. (2013) caution us to the issue that recurring to a different group of experts might lead to different results. Although the Delphi study definition discourages the danger in this issue, as researchers we must acknowledge this caveat. There is therefore a need to add extra support to the results by using other qualitative research techniques, such as Oliveira and Ferreira (2012) Business Narrative Modelling Language technique, to examine and decode responses given by a different group of experts.

By observing the literature related to information systems and technology adoption, we see that authors such as Zhu et al. (2006) argue that the technology adoption process is not a unique 
stage event, but a multi-stage process comprising three phases, thus allowing for a more precise characterization of the impact produced by each determinant. Considering all the arguments and perceptions achieved in the execution of the present research, it is our belief that a more comprehensive characterization of the SNS adoption process at firm level would be possible by performing a mixed methodology supported study aimed at understanding the technologies' adoption process stages, and collecting the data at the European level, involving about 100 firms from at least 15 countries.

\section{Conclusions}

Performing the described research activities allowed us to understand that despite their enormous potential to firms, the determinants that influence the adoption of social networks sites at the firm level are yet to be extensively analysed. Based on this realization and our use of a mixed methodology, a Delphi study involving 25 experts was defined, planned, and implemented in order for the experts to reach a consensus about what variables would have the most influence on firms' adoption of SNS. The variables emerging from this first study were than incorporated into a research model empirically validated by an online survey that received 247 valid responses. The empirical data lead us to perceive that the top management support toward the implementation of SNS related business initiatives, the guarantee of alignment between the firm's SNS strategic plan and the overall business plan, the concept of using SNS for gaining competitive advantages against competitors, and the competitive pressures on firms to use SNS, are the determinants with the most impact on the adoption of social networks sites at the firm level. The contextual analysis of these findings also allow to understand that despite the popular belief to the contrary, the security and privacy context (and its inherent variables) are not influential (in the present study) to the SNS adoption process.

\section{References}

Agarwal, R., Gupta, A., Kraut, R., 2008. The interplay between digital and social networks. Inf. Syst. Res. 19, 243-252.

Alam, S., Ali, M., Jani, M., 2011. An empirical study of factors affecting electronic commerce adoption among SMEs in Malaysia. J. Bus. Econ. Manage. 12, 375399.

Aversano, L., Grasso, C., Tortorella, M., 2013. A literature review of business/IT alignment strategies, enterprise information systems. Springer, 471-488.

Baird, C., Parasnis, G., 2011. From social media to socual customer relationship management. Strat. Leadership 39, 30-37.

Bassellier, G., Pinsonneault, A., 1998. Assessing top management support for information technologies: a new conceptualization and measure. ECIS, 15361543.

Benbasat, I., Wang, W., 2005. Trust in and adoption of online recommendation agents. J. Assoc. Inform. Syst. 6, 4.

BenMark, G., 2014. Why the COO should lead social-media customer service. McKinsey Quart.

Berthon, P., Pitt, L., Plangger, K., Shapiro, D., 2012. Marketing meets Web 2.0, social media, and creative consumers: implications for international marketing strategy. Bus. Horiz. 55, 261-271.

Boyd, D., Ellison, N., 2007. Social network sites: definition, history, and scholarship. J. Computer-Mediated Commun. 13, \#11.

Brandtzæg, P., Lüders, M., Skjetne, J., 2010. Too many Facebook “Friends"? Content sharing and sociability versus the need for privacy in social network sites. Int. J. Human-Computer Interact. 26, 1006-1030.

Bughin, J., Byers, A., Chui, M., 2011. How social technologies are extending the organization. McKinsey Quart. 20, 1-10.

Byrd, T., Lewis, B., Bryan, R., 2006. The leveraging influence of strategic alignment on IT investment: an empirical examination. Inform. Manage. 43, 308-321.

Cafiso, S., Di Graziano, A., Pappalardo, G., 2013. Using the Delphi method to evaluate opinions of public transport managers on bus safety. Saf. Sci. 57, 254-263.

Carter, T., 2016. How Facebook Is Diversifying the Online Customer Engagement Experience, AudienceBloom.

Cebi, S., 2013. Determining importance degrees of website design parameters based on interactions and types of websites. Decis. Support Syst. 54, 1030-1043.
Chang, B., Hai, P., Seo, D., Lee, J., Yoon, S., 2013. The determinant of adoption in cloud computing in Vietnam, International Conference on Computing, Management and Telecommunications (ComManTel 2013) Vietnam, pp. 407-409.

Chatterjee, D., Grewal, R., Sambamurthy, V., 2002. Shaping up for e-commerce: institutional enablers of the organizational assimilation of web technologies. MIS Quart. 26, 65-89.

Chen, L., 2010. Business-IT alignment maturity of companies in China. Inform. Manage. 47, 9-16.

Cheng, H., 2010. Seeking knowledge or gaining legitimacy? Role of social networks on new practice adoption by OEM suppliers. J. Bus. Res. 63, 824-831.

Chong, A., Ooi, K., Lin, B., Raman, M., 2009. Factors affecting the adoption level of ccommerce: an empirical study. J. Computer Inform. Syst. 50, 13.

Chui, M., Manyika, J., Bughin, J., Dobbs, R., Roxburgh, C., Sarrazin, H., Sands, G., Westergren, M., 2012. The social economy: unlocking value and productivity through social technologies. McKinsey Global Institute, p. 184.

Churchill, G., 1979. A paradigm for developing better measures of marketing constructs. J. Mark. Res. 16, 64-73.

Chwelos, P., Benbasat, I., Dexter, A., 2001. Research report: empirical test of an edi adoption model. Inform. Syst. Res. 12, 304-321.

Claypoolle, T., 2014. Privacy and social media. Business Law Today.

Cragg, P., King, M., Hussin, H., 2002. IT alignment and firm performance in small manufacturing firms. J. Strateg. Inf. Syst. 11, 109-132.

Creswell, J., 2013. Research design: qualitative, quantitative, and mixed methods approaches. Sage Publications.

Curtis, L., Edwards, C., Fraser, K., Gudelsky, S., Holmquist, J., Thornton, K., Sweetser, K., 2010. Adoption of social media for public relations by nonprofit organizations. Public Relat. Rev. 36, 90-92.

Dalkey, N., Helmer, O., 1963. An experimental application of the Delphi method to the use of experts. Manage. Sci. 9, 458-467.

DeMers, J., 2016. Don't Make Social Media Your Company's Mouth - Make It Your Eyes And Ears, Forbes Entrepreneus.

Dimaggio, P., Powel, W., 1983. The iron cage revisited - institutional isomorphism and collective rationality in organizational fields. Am. Sociol. Rev. 48, 147-160.

Divol, R., Edelman, D., Sarrazin, H., 2012. Demystifying social media. McKinsey Quart.

Doll, W., 1985. Avenues for top management involvement in successful MIS development. MIS Quart., 17-35

Durkin, M., McGowan, P., McKeown, N., 2013. Exploring social media adoption in small to medium-sized enterprises in Ireland. J. Small Bus. Enterprise Develop. 20, 716-734.

Escobar-Rodriguez, T., Monge-Lozano, P., 2012. The acceptance of Moodle technology by business administration students. Comput. Educ. 58, 1085-1093.

Everson, M., Gundlach, E., Miller, J., 2013. Social media and the introductory statistics course. Comput. Hum. Behav. 29, A69-A81.

Fang, X., Hu, P., Li, Z., Tsai, W., 2013. Predicting adoption probabilities in Social Networks. Inform. Syst. Res.

Fornell, C., Larcker, D., 1981. Evaluating structural equation models with unobservable variables and measurement error. J. Market. Res. (JMR), 18.

Gallego, D., Bueno, S., 2014. Exploring the application of the Delphi method as a forecasting tool in Information Systems and Technologies research. Technol. Anal. Strateg. Manage. 26, 987-999.

Gesenhues, A., 2013. Survey: 46\% Of Marketers Have Content Marketing Strategy, Only 25\% Track Social Media Results, Marketing Land.

Goluchowicz, K., Blind, K., 2011. Identification of future fields of standardisation: an explorative application of the Delphi methodology. Technol. Forecast. Soc. Chang. 78, 1526-1541.

Gorla, N., Somers, T., Wong, B., 2010. Organizational impact of system quality, information quality, and service quality. J. Strateg. Inf. Syst. 19, 207-228.

Graefe, A., Armstrong, J., 2011. Comparing face-to-face meetings, nominal groups, Delphi and prediction markets on an estimation task. Int. J. Forecast. 27, 183195.

Hair Jr, J., Hult, G., Ringle, C., Sarstedt, M., 2013. A primer on partial least squares structural equation modeling (PLS-SEM). Sage Publications.

Hanna, R., Rohm, A., Crittenden, V., 2011. We're all connected: the power of the social media ecosystem. Bus. Horiz. 54, 265-273.

Haythornthwaite, C., 2005. Social networks and Internet connectivity effects. Inform. Commun. Soc. 8, 125-147.

Heiko, A., 2012. Consensus measurement in Delphi studies: review and implications for future quality assurance. Technol. Forecast. Soc. Chang. 79, 1525-1536.

Hendersen, J., Sifonis, J., 1988. The value of strategic IS planning: understanding consistency, validity and IS markets. MIS Quart. 12, 187-200.

Henseler, J., Ringleand, C., Sinkovics, R., 2009. The use of partial least squares path modelling in international marketing. New Challenges Int. Market. 20, 277-319.

Hsu, P., Kraemer, K., Dunkle, D., 2006. Determinants of E-Business Use in U.S firms Int. J. Electron. Comm. 10, 9-45.

Huang, L., 2010. A resource-based analysis of IT personnel capabilities and strategic alignment. J. Res. Pract. Inform. Technol., 42

Hung, P., Chiu, D., Fung, W., Cheung, W., Wong, R., Choi, S., Kafeza, E., Kwok, J., Pun, J., Cheng, V., 2007. End-to-end privacy control in service outsourcing of human intensive processes: a multi-layered Web service integration approach. Inf. Syst. Front. 9, 85-101.

Huy, Q., Shipilov, A., 2012. The key to social media success within organizations MIT Sloan Manage. Rev. 54, 73-81.

Iacovou, C., Benbasat, I., Dexter, A., 1995. Electronic data interchange and small organizations: adoption and impact of technology. MIS Quart. 19, 465-485. 
Ifinedo, P., 2011. An empirical analysis of factors influencing internet/e-Business technologies adoption by SMEs in Canada. Int. J. Inform. Technol. Decis. Making 10, 731-766.

ITPRO, 2014. The technology behind social media, ITPRO - Strategy News.

Jeyaraj, A., Rottman, J., Lacity, M., 2006. A review of the predictors, linkages, and biases in IT innovation adoption research. J. Inform. Technol. 21, 1-23.

Johnson, J.W., Lebreton, J.M., 2004. History and use of relative importance indices in organizational research. Org. Res. Methods 7, 238-257.

Joo, Y., Kim, Y., Yang, S., 2011. Valuing customers for social network services. J. Bus. Res. 64, 1239-1244.

Jussila, J., Kärkkäinen, H., Aramo-Immonen, H., 2014. Social media utilization in business-to-business relationships of technology industry firms. Comput. Hum. Behav. 30, 606-613.

Kane, G., Alavi, M., Labianca, G., Borgatti, S., 2012. What's different about socia media networks? A framework and research agenda. MIS Quart.

Kaplan, A., Haenlein, M., 2010. Users of the world, unite! The challenges and opportunities of Social Media. Bus. Horiz. 53, 59-68.

Kaplan, B., Duchon, D., 1988. Combining qualitative and quantitative methods in information systems research: a case study. MIS Quart., 571-586

Kearns, G., Lederer, A., 2003. A resource-based view of strategic IT alignment: how knowledge sharing creates competitive advantage. Decision Sci. 34, 1-29.

Kearns, G., Lederer, A., 2004. The impact of industry contextual factors on IT focus and the use of IT for competitive advantage. Inform. Manage. 41, 899-919.

Keil, M., Tiwana, A., Bush, A., 2002. Reconciling user and project manager perceptions of IT project risk: a Delphi study. Inform. Syst. J. 12, 103-119.

Kietzmann, J., Hermkens, K., McCarthy, I., Silvestre, B., 2011. Social media? Get serious! Understanding the functional building blocks of social media. Bus. Horiz. 54, 241-251.

Kim, W., Jeong, O., Lee, S., 2010. On social Web sites. Inform. Syst. 35, 215-236.

Ko, H., 2013. The determinants of continuous use of social networking sites: an empirical study on Taiwanese journal-type bloggers' continuous self-disclosure behavior. Electron. Commer. Res. Appl. 12, 103-111.

Kuan, K., Chau, P., 2001. A perception-based model for EDI adoption in small businesses using a technology-organization-environment framework. Inform. Manage. 38, 507-521.

Landeta, J., 2006. Current validity of the Delphi method in social sciences. Technol. Forecast. Soc. Chang. 73, 467-482.

Laroche, M., Habibi, M., Richard, M., Sankaranarayanan, R., 2012. The effects of social media based brand communities on brand community markers, value creation practices, brand trust and brand loyalty. Comput. Hum. Behav. 28, 1755-1767.

Leonardi, P., 2014. Social media, knowledge sharing, and innovation: toward a theory of communication visibility. Inform. Syst. Res. 25, 796-816.

Leonardi, P., Huysman, M., Steinfield, C., 2013. Enterprise social media: definition, history, and prospects for the study of social technologies in organizations. J. Comput. Med. Commun. 19, 1-19.

Li, Q., Wang, C., Wu, J., Li, J., Wang, Z., 2011. Towards the business-information technology alignment in cloud computing environment: an approach based on collaboration points and agents. Int. J. Comput. Integr. Manuf. 24, 1038-1057.

Liang, H., Nilesh, S., Hu, Q., Xue, Y., 2007. Assimilation of enterprise systems: the effect of institutional pressures and the mediating role of top management. MIS Quart. 31, 59-87.

Lin, H.-F., Lin, S.-M., 2008. Determinants of e-business diffusion: a test of the technology diffusion perspective. Technovation 28, 135-145.

Liu, C., Sia, C., Wei, K., 2008. Adopting organizational virtualization in B2B firms: an empirical study in Singapore. Inform. Manage. 45, 429-437.

Luo, X., Gurung, A., Shim, J., 2010. Understanding the determinants of user acceptance of enterprise instant messaging: an empirical study. J. Org. Comput. Electron. Comm. 20, 155-181.

Malik, A., Dhir, A., Nieminen, M., 2016. Uses and Gratifications of digital photo sharing on Facebook. Telemat. Inform. 33, 129-138.

Marques, A., Santos, L., Soares, P., Santos, R., Oliveira-Tavares, A., Mota, J., Carvalho, J., 2011. A proposed adaptation of the European Foundation for Quality Management Excellence Model to physical activity programmes for the elderly-development of a quality self-assessment tool using a modified Delph process. Int. J. Behav. Nutr. Phys. Act. 8, 104.

Martins, J., Gonçalves, R., Oliveira, T., Pereira, J., Cota, M., 2014. Social networks sites adoption at firm level: A literature review, CISTI'2014 - Iberian Conference on Information Systems and Technologies, Barcelona, Spain.

Maxwell, J., 2015. Expanding the history and range of mixed methods research. J. Mixed Methods Res.

Mergel, I., 2013. Social media adoption and resulting tactics in the U.S. federal government. Govern. Inform. Quart. 30, 123-130.

Meske, C., Stieglitz, S., 2013. Adoption and Use of Social Media in Small and Medium-Sized Enterprises. In: Harmsen, F., Proper, H. (Eds.), Practice-Driven Research on Enterprise Transformation. Springer, Berlin Heidelberg, pp. 61-75.

Messerschmidt, C., Hinz, O., 2013. Explaining the adoption of grid computing: an integrated institutional theory and organizational capability approach. J. Strateg. Inf. Syst. 22, 137-156.

Michaelidou, N., Siamagka, N., Christodoulides, G., 2011. Usage, barriers and measurement of social media marketing: an exploratory investigation of small and medium B2B brands. Ind. Mark. Manage. 40, 1153-1159.

Milwood, P., Marchiori, E., Zach, F., 2013. A comparison of social media adoption and use in different countries: the case of the United States and Switzerland. J. Travel Tourism Market. 30, 165-168.
Mirchandani, D., Lederer, A., 2012. Shared objectives and IT achievements: CIO and business manager perspectives. IT Professional, 44-50.

Mislove, A., Marcon, M., Gummadi, K., Druschel, P., Bhattacharjee, B., 2007. Measurement and analysis of online social networks, Proceedings of the 7th ACM SIGCOMM conference on Internet measurement. ACM, San Diego, California, USA, pp. 29-42.

Moorhead, S., Hazlett, Harison, Carroll, Irwin, Hoving, C., 2013. A new dimension of health care: systematic review of the uses, benefits, and limitations of social media for health communication. J. Med. Internet Res., 15

Muñoz, A., Gonzalez, J., Maña, A., 2012. A performance-oriented monitoring system for security properties in cloud computing applications. Comput. J. 55, 979-994.

Muñoz, F., Strotmeyer, K., 2010. Demystifying social media. J. Student Affairs Res. Prac. 47, 123-127.

Nah, S., Saxton, G., 2013. Modeling the adoption and use of social media by nonprofit organizations. New Media Soc. 15, 294-313.

Neuman, W., 2005. Social research methods: quantitative and qualitative approaches. Allyn and Bacon.

Nevo, S., Wade, M., 2011. Firm-level benefits of IT-enabled resources: a conceptual extension and an empirical assessment. J. Strateg. Inf. Syst. 20, 403-418.

Nolan, R., McFarlan, F., 2005. Information technology and the board of directors. Harvard Bus. Rev. 83, 96.

Nosek, J., McManus, M., 2008. Collaboration challenges: bridging the IT support gap. Inform. Syst. Manage. 25, 3-7.

Okoli, C., Pawlowski, S., 2004. The Delphi method as a research tool: an example, design considerations and applications. Inform. Manage. 42, 15-29.

Oliveira, M., Ferreira, J., 2012. Business Narrative Modelling Language (BNML) representations: a storyline view and a plot view of how interoperability is an antecedent of innovation at IP BRICK. African J. Bus. Manage. 6, 5338-5361.

Oliveira, T., Dhillon, G., 2015. From adoption to routinization of B2B e-commerce: understanding patterns across Europe. J. Global Inf. Manage. (JGIM) 23, 24-43.

Oliveira, T., Martins, M., 2011. Literature review of information technology adoption models at firm level. Electron. J. Inform. Syst. Eval. 14, 110-121.

Oliveira, T., Thomas, M., Espadanal, M., 2014. Assessing the determinants of cloud computing adoption: an analysis of the manufacturing and services sectors. Inform. Manage.

Pai, P., Arnott, D., 2013. User adoption of social networking sites: eliciting uses and gratifications through a means-end approach. Comput. Hum. Behav. 29, 10391053.

Paré, G., Cameron, A., Poba-Nzaou, P., Templier, M., 2013. A systematic assessment of rigor in information systems ranking-type Delphi studies. Inform. Manage. 50, 207-217.

Patel, N., 2016. Don't make this one stupid mistake with your social media, Forbes Magazine. Forbes Entrepreneus.

Patel, S., 2015. 7 Examples of Companies Using Social Media Right, Medium.com.

Patterson, M., 2015. 10 Brands doing an amazing job on social media. Social Times, Adweek

Pereira, J., Martins, J., Gonçalves, R., Santos, V., 2014. CRUDI Framework Proposal: Financial Industry Application. Behav. Inform. Technol.

Perrigot, R., Kacker, M., Basset, G., Cliquet, G., 2012. Antecedents of early adoption and use of social media networks for stakeholder communications evidence from franchising. J. Small Bus. Manage. 50, 539-565.

Petry, K., Maes, B., Vlaskamp, C., 2007. Operationalizing quality of life for people with profound multiple disabilities: a Delphi study. J. Intellect. Disabil. Res. 51, 334-349.

Podsakoff, P., MacKenzie, S., Lee, J., Podsakoff, N., 2003. Common method biases in behavioral research: a critical review of the literature and recommended remedies. J. Appl. Psychol. 88, 879.

Premkumar, G., Roberts, M., 1999. Adoption of new information technologies in rural small businesses. Omega 27, 467-484.

Ranganathan, C., Dhaliwal, J.S., Teo, T.S.H., 2004. Assimilation and diffusion of web technologies in supply-chain management: an examination of key drivers and performance impacts. Int. J. Electron. Comm. 9, 127-161.

Reddick, C., Norris, D., 2013. Social media adoption at the American grass roots: Web 2.0 or 1.5 ? Govern. Inform. Quart. 30, 498-507.

Reich, B., Benbasat, I., 2013. Measuring the information systems-business strategy relationship. Strat. Inform. Manage., 265

Rodríguez-Mañas, L., Féart, C., Mann, G., Viña, J., Chatterji, S., Chodzko-Zajko, W., Harmand, M., Bergman, H., Carcaillon, L., Nicholson, C., 2013. Searching for an operational definition of frailty: a Delphi method based consensus statement. The frailty operative definition-consensus conference project. J. Gerontol. Biol. Sci. Med. Sci. 68, 62-67.

Rowe, G., Wright, G., 2011. The Delphi technique: past, present, and future prospects-introduction to the special issue. Technol. Forecast. Soc. Chang. 78, $1487-1490$

Ruivo, P., Oliveira, T., Neto, M., 2014. Examine ERP post-implementation stages of use and value: empirical evidence from Portuguese SMEs. Int. J. Account. Inform. Syst.

Ryans, A., 1974. Estimating consumer preferences for a new durable brand in an established product class. J. Mark. Res. 11, 434-443.

Sarosa, S., 2012. Adoption of Social Media Networks by Indonesian SME: A Case Study. Proc. Econ. Finance 4, 244-254.

Scheepers, H., Scheepers, R., 2008. A process-focused decision framework for analyzing the business value potential of IT investments. Inf. Syst. Front. 10, 321-330. 
Sherchan, W., Nepal, S., Paris, C., 2013. A survey of trust in social networks. ACM Comput. Surv. 45, 1-33.

Sinclaire, J., Vogus, C., 2011. Adoption of social networking sites: an exploratory adaptive structuration perspective for global organizations. Inf. Technol. Manage. 12, 293-314.

Skulmoski, G., Hartman, F., Krahn, J., 2007. The Delphi Method for Graduate Research. J. Inform. Technol. Edu. 6, 1-21.

Smith, H., Dinev, T., Xu, H., 2011. Information privacy research: an interdisciplinary review. MIS Quart. 35, 989-1016.

Soares, D., Amaral, L., 2011. Information systems interoperability in public administration: identifying the major acting forces through a Delphi study. J. Theor. Appl. Electron. Comm. Res. 6, 61-94.

Straub, D., 1989. Validating instruments in MIS research. MIS Quart. 13, 147-169.

Sutton, S., Arnold, V., 2013. Focus group methods: Using interactive and nominal groups to explore emerging technology-driven phenomena in accounting and information systems. Int. J. Acc. Inform. Syst. 14, 81-88.

Teng, C., 2015. Drivers of interdependence and network convergence in social networks in virtual communities. Electron. Commer. Res. Appl. 14, 204-212.

Teo, H., Wei, K., Benbasat, I., 2003. Predicting intention to adopt interorganizational linkages: an institutional perspective. MIS Quart. 27, 19-49.

Teo, T., Ranganathan, C., Dhaliwal, J., 2006. Key dimensions of inhibitors for the deployment of web-based business-to-business electronic commerce. IEEE Trans. Eng. Manage. 53, 395-411.

Thomas, M., Costa, D., Oliveira, T., 2015. Assessing the role of IT-enabled process virtualization on Green IT adoption. Inf. Syst. Front., 1

Tonidandel, S., LeBreton, J., 2011. Relative importance analysis: a useful supplement to regression analysis. J. Bus. Psychol. 26, 1-9.

Trainor, K., Andzulis, J., Rapp, A., Agnihotri, R., 2013. Social media technology usage and customer relationship performance: a capabilities-based examination of social CRM. J. Bus. Res.

van den Hooff, B., de Winter, M., 2011. Us and them: a social capital perspective on the relationship between the business and IT departments. Eur. J. Inform. Syst. $20,255-266$.

Varho, V., Rikkonen, P., Rasi, S., 2016. Futures of distributed small-scale renewable energy in Finland - a Delphi study of the opportunities and obstacles up to 2025. Technol. Forecast. Soc. Chang. 104, 30-37.

Vaughan-Nichols, S., 2010. How social networking works, IT World.

Venkatesh, V., Bala, H., 2012. Adoption and impacts of interorganizational business process standards: role of partnering synergy. Inform. Syst. Res. 23, 1131-1157.
Venkatesh, V., Brown, S., Bala, H., 2013. Bridging the qualitative-quantitative divide: guidelines for conducting mixed methods research in information systems. MIS Quart., 37

Venkatesh, V., Thong, J., Xu, X., 2012. Consumer acceptance and use of information technology: extending the unified theory of acceptance and use of technology. MIS Quart. 36, 157-178.

Voss, K., Kumar, A., 2013. The value of social media: are universities successfully engaging their audience? J. Appl. Res. Higher Edu. 5, 156-172.

Wang, Y.-M., Wang, Y.-S., Yang, Y.-F., 2010. Understanding the determinants of RFID adoption in the manufacturing industry. Technol. Forecast. Soc. Chang. 77, 803815.

Worrell, J., Di Gangi, P., Bush, A., 2013a. Exploring the use of the Delphi method in accounting information systems research. Int. J. Acc. Inform. Syst. 14, 193-208.

Worrell, J., Wasko, M., Johnston, A., 2013b. Social network analysis in accounting information systems research. Int. J. Acc. Inform. Syst. 14, 127-137.

Wu, L., 2013. Social network effects on productivity and job security: evidence from the adoption of a social networking tool. Inform. Syst. Res. 24, 30-51.

Xu, J., Quaddus, M., 2012. Examining a model of knowledge management systems adoption and diffusion: a partial least square approach. Knowl.-Based Syst. 27, $18-28$.

Xu, K., Guo, X., Li, J., Lau, R., Liao, S., 2012. Discovering target groups in social networking sites: an effective method for maximizing joint influential power Electron. Commer. Res. Appl. 11, 318-334.

Xu, S., Zhu, K., Gibbs, J., 2004. Global technology, local adoption: a cross-country investigation on Internet adoption by companies in the United States and China. Electron. Markets 14, 13-24.

Yoon, T., George, J., 2013. Why aren't organizations adopting virtual worlds? Comput. Hum. Behav. 29, 772-790.

Young, R., Jordan, E., 2008. Top management support: Mantra or necessity? Int. J. Project Manage. 26, 713-725.

Yuan, Y., Zhao, X., Liao, Q., Chi, C., 2013. The use of different information and communication technologies to support knowledge sharing in organizations: from e-mail to micro-blogging. J. Am. Soc. Inform. Sci. Technol. 64, 1659-1670.

Zafar, H., Ko, M., Osei-Bryson, K., 2015. The value of the CIO in the top management team on performance in the case of information security breaches. Inf. Syst. Front., 1-11

Zhu, K., Kraemer, K., Xu, S., 2006. The process of innovation assimilation by firms in different countries: a technology diffusion perspective on e-business. Manage. Sci. 52, 1557-1576 